\title{
The Smooth Monostratified Ganglion Cell: Evidence for Spatial Diversity in the Y-Cell Pathway to the Lateral Geniculate Nucleus and Superior Colliculus in the Macaque Monkey
}

\author{
Joanna D. Crook, ${ }^{1,2}$ Beth B. Peterson, ${ }^{1}$ Orin S. Packer, ${ }^{1}$ Farrel R. Robinson, ${ }^{1,5}$ Paul D. Gamlin, ${ }^{3}$ John B. Troy, ${ }^{4}$ and \\ Dennis M. Dacey ${ }^{1,5}$ \\ ${ }^{1}$ Department of Biological Structure and ${ }^{2}$ Graduate Program in Neurobiology and Behavior, University of Washington, Seattle, Washington 98195 , \\ ${ }^{3}$ Department of Vision Sciences, University of Alabama at Birmingham, Birmingham, Alabama 35294, ${ }^{4}$ Department of Biomedical Engineering, \\ Northwestern University, Evanston, Illinois 60208, and ${ }^{5}$ Washington National Primate Research Center, Seattle, Washington 98195
}

In the primate visual system approximately 20 morphologically distinct pathways originate from retinal ganglion cells and project in parallel to the lateral geniculate nucleus (LGN) and/or the superior colliculus. Understanding of the properties of these pathways and the significance of such extreme early pathway diversity for later visual processing is limited. In a companion study we found that the magnocellular LGN-projecting parasol ganglion cells also projected to the superior colliculus and showed Y-cell receptive field structure supporting the hypothesis that the parasol cells are analogous to the well studied alpha-Y cell of the cat's retina. We here identify a novel ganglion cell class, the smooth monostratified cells, that share many properties with the parasol cells. Smooth cells were retrogradely stained from tracer injections made into either the LGN or superior colliculus and formed inner-ON and outer-OFF populations with narrowly monostratified dendritic trees that surprisingly appeared to perfectly costratify with the dendrites of parasol cells. Also like parasol cells, smooth cells summed input from L- and M-cones, lacked measurable S-cone input, showed high spike discharge rates, high contrast and temporal sensitivity, and a Y-cell type nonlinear spatial summation. Smooth cells were distinguished from parasol cells however by smaller cell body and axon diameters but $\sim 2$ times larger dendritic tree and receptive field diameters that formed a regular but lower density mosaic organization. We suggest that the smooth and parasol populations may sample a common presynaptic circuitry but give rise to distinct, parallel achromatic spatial channels in the primate retinogeniculate pathway.

Key words: primate; superior colliculus; retina; magnocellular LGN; Y-cell; spatial vision

\section{Introduction}

Approximately 20 anatomically distinct retinal ganglion cell populations project from the retina to the brain, but the meaning of such extreme pathway diversity for visual processing remains unclear (Meister and Berry, 1999; Masland and Raviola, 2000; Roska and Werblin, 2001; Rockhill et al., 2002; Dacey, 2004; Callaway, 2005; Masland and Martin, 2007). The simplest, and longheld, view is that physiologically diverse retinal pathways project in parallel to an equally diverse array of brainstem targets (Cleland et al., 1971; Cleland and Levick, 1974a; Stone, 1983). Thus retinal input to the geniculocortical relay would arise from a few pathways that subserve perception of form, color, and motion;

\footnotetext{
Received June 27, 2008; revised 0ct. 14, 2008; accepted 0ct. 16, 2008.

This work was supported by the Paul Kayser International Award from the Retina Research Foundation (D.M.D.) and by National Institutes of Health Grants EY06678 (D.M.D.) and EY09380 (P.D.G.); the Vision Research Center, EY01730; the Tissue Distribution Program of National Primate Research Center at the University of Washington RR00166; and National Science Foundation Grant DBI-0551852 (J.B.T.). We thank Julian Vreislander for programming assistance through the Vision Core and the development of the Vision Core Toolbox (http://vrc.biostr. washington.edu/vct/vct_home.html). We also thank Barry Lee for advice and discussion, Toni Haun for technical assistance, and Anita Hendrickson for comments on this manuscript.

Correspondence should be addressed to Dennis M. Dacey, Department of Biological Structure, University of Washington, Seattle, WA 98195. E-mail: dmd@u.washington.edu.

DOI:10.1523/JNEUROSCI.2986-08.2008

Copyright $\odot 2008$ Society for Neuroscience ～0270-6474/08/2812654-18\$15.00/0
}

other pathways to the superior colliculus and to several other smaller targets would control ancillary visuomotor functions such as saccadic eye movements, pupillary and optokinetic reflexes, and circadian rhythm (e.g., Kaplan et al., 1990). The ganglion cell populations however far outnumber envisioned functional roles and many ganglion cell types show branching projections to multiple targets; indeed most mammalian retinal ganglion cell populations project to the superior colliculus (Vaney et al., 1981; Stein and Berson, 1995; Isayama et al., 2000). A strict parcellation therefore by central target and broad functional role appears too simple a rationale for extreme visual pathway diversity.

Recent evidence points to such diversity in the primate retinogeniculate pathway. Projections from chromatic midget and achromatic parasol cells to the parvocellular and magnocellular LGN layers respectively [for review, see Dacey (2004), Lennie and Movshon (2005), Field and Chichilnisky (2007), and Solomon and Lennie (2007)] and a third, blue-yellow chromatic pathway, likely via the koniocellular LGN layers, have been well documented (Dacey and Lee, 1994; Martin et al., 1997; Szmajda et al., 2006). Further the use of a sensitive retrograde labeling method revealed the fine dendritic morphology of several additional ganglion cell populations that also project to the LGN (Dacey et al., 2003), suggesting an anatomical basis for physiological classes of 


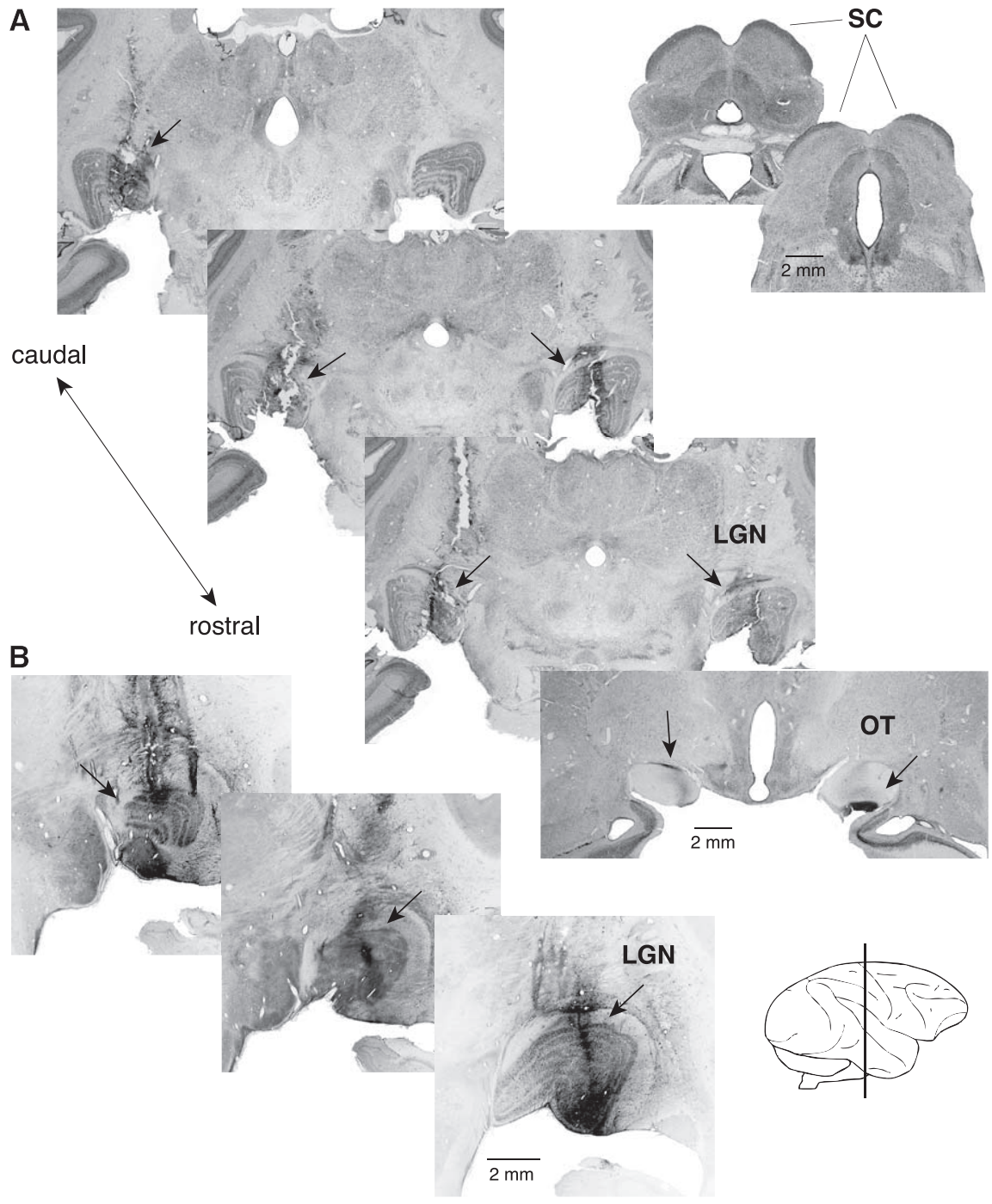

Figure 1. Assessment of biotinylated rhodamine-dextran tracer injections made into the macaque LGN. Serial $50 \mu \mathrm{m}$ sections were processed for HRP histochemistry to demonstrate location of tracts and biotinylated tracer. $\boldsymbol{A}$, Sections through LGN spanning $2 \mathrm{~mm}$ near the center of the rostrocaudal extent of the nucleus shows multiple tracts and tracer deposits in both left and right LGN (arrows, top left 3 panels). In a section taken through the optic tract rostral to the LGN (front, bottom, 0T, optic tract) retrogradely transported tracer is present (dark zones indicated by arrows) in restricted location within the tract. Inset, above right, illustrates two sections taken from rostral and caudal level of the superior colliculus (SC), confirming no injection sites or tracer deposits were observed at midbrain levels. $\boldsymbol{B}$, Higher magnification micrographs from a second brain also spanning $\sim 2 \mathrm{~mm}$ of the LGN rostrocaudal extent illustrates separate injection tracts terminating in the parvocellular layers (top) and magnocellular layers (bottom) (labels as in $\boldsymbol{A}$ ). Approximate plane of tissue section is indicated by the line drawn through the whole brain schematic at the lower right.

geniculate relay cells not previously well appreciated (Irvin et al., 1993; Holdefer and Norton, 1995; White et al., 2001; Tailby et al., 2007). With the exception of a unique, inherently photoreceptive ganglion cell (Dacey et al., 2005), the receptive field properties of diverse remaining ganglion cell types remain largely uncharacterized (Dacey, 2004). Here we report on the identification of a novel ganglion cell population, the smooth monostratified cells, that are consistently retrogradely labeled from tracer injections made into either the LGN or superior colliculus. The morphology and physiology of the smooth cells are compared with that of the magnocellular-projecting parasol cells which we suggest in a companion study are the primate counterpart of the mammalian alpha-Y cells (Crook et al., 2008). These two cell classes share many anatomical and physiological properties, most notably a branching LGN-collicular projection, precise dendritic costrati- fication of ON and OFF types within the inner plexiform layer, high achromatic contrast and temporal sensitivity, and a Y-cell receptive field structure. However the smooth cells can be uniquely distinguished from the parasol cells by larger dendritic and receptive field diameters and from mammalian alpha cells in general by their relatively smaller soma and intraretinal axon diameters. We suggest that the smooth and parasol populations could contribute to visual pathway diversity by sampling a common presynaptic circuitry but giving rise to distinct and parallel spatial channels.

\section{Materials and Methods}

General approach. The specific methods and general strategy follow closely that given in the companion study (Crook et al., 2008). Briefly, our goal was to place small injections of the retrograde tracer, rhodamine dextran, into physiologically identified locations within either the superior colliculus or LGN. The tracer was chosen to permit retrogradely labeled retinal ganglion cells to be intracellularly stained by a photodynamic reaction elicited by brief exposure of the retina to epifluorescent illumination after the retina was dissected and placed in vitro (Dacey et al., 2003). Ganglion cell types whose dendritic trees were fully revealed by photodynamic staining in vitro could then be observed microscopically and selected on the basis of morphological criteria for intracellular recording and characterization of basic receptive field properties. In this way we hoped to directly link ganglion cell morphological type, with central projection and receptive field properties (Dacey et al., 2005).

Tracer injections. Experiments were performed on 22 adult macaque monkeys (Macaca mulatta). The LGN was targeted in 15 animals and the superior colliculus in 7 animals. Some anatomical data taken from the first 7 LGN targeted animals has been previously published (Dacey et al., 2003). All procedures involving primates were approved by the Institutional Animal Care and Use Committee (IACUC) at the University of Washington and conform to PHS Policy on Humane Care and Use of Laboratory Animals. All procedures for animal surgery, handling, physiological recording, tracer injections, and subsequent tissue processing are identical to that given in the companion study (Crook et al., 2008). To help accurately localize injection sites, tracer injections were made while simultaneously recording visually evoked activity in either the magnocellular or parvocellular LGN laminas or the retinorecipient collicular layers via the injection pipette.

Retinal preparation and cell targeting. The in vitro whole-mount retina preparation has been described previously (Dacey and Lee, 1994; Dacey et al., 1996) and is the same as that described in the companion study (Crook et al., 2008). In the companion study we also describe the use of the retrograde photostaining method for identifying the morphology of parasol ganglion cells and these methods have also been given in detail previously (Dacey et al., 2003). Briefly, photostaining is effected by exposing ganglion cells in vitro that have been retrogradely labeled with rhodamine dextran to epi-illumination for several seconds; the light ex- 

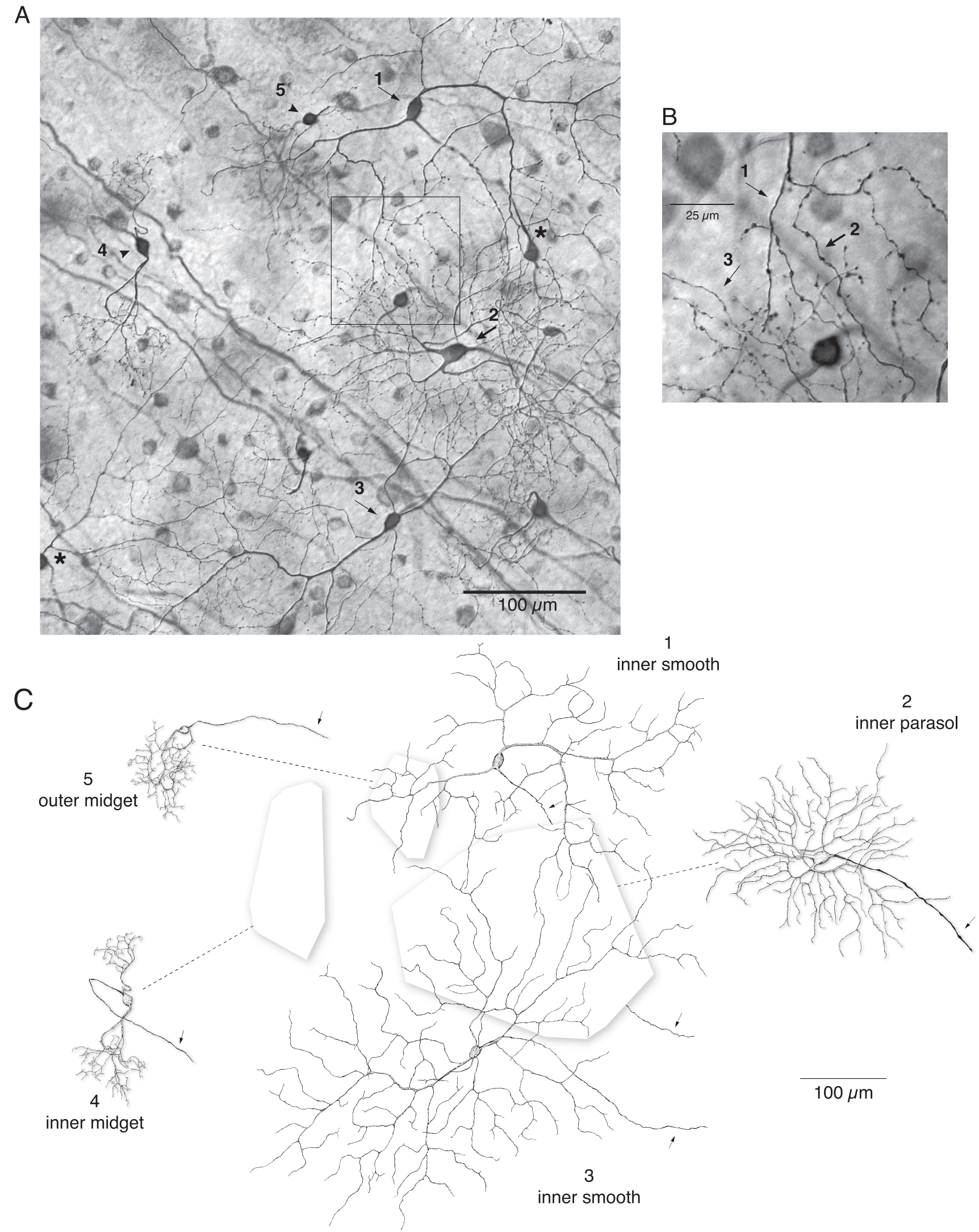

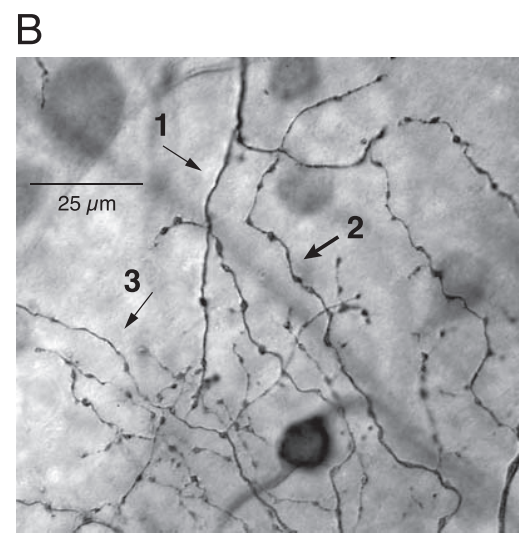

Figure 2. Smooth monostratified cells project to the LGN. $A$, Patch of HRP stained ganglion cells in whole-mount retina retrogradely tracer labeled from biotinylated rhodamine dextran injections into the LGN and photostained in vitro (see Materials and Methods for details). Two neighboring smooth cells (thin arrows), one parasol cell (thick arrow), and two midget cells (arrowheads) are numbered 1-5 and their detailed dendritic morphology is shown in $\boldsymbol{C}$. Boxed area is shown magnified in $\boldsymbol{B}$. $\boldsymbol{B}$, Apparent costratification of the two inner smooth cells and inner parasol cell is illustrated in enlarged view for the region of overlapping dendrites indicated by the box in $\boldsymbol{A}$. The numbers 1,2 , and 3 indicate dendrites of the respective cells labeled in $\boldsymbol{A}$. $\boldsymbol{C}$, Camera Lucida tracings of cells labeled 1-5 in $\boldsymbol{A}$. The smooth cells are shown in their correct respective positions to illustrate their interdigitating dendrites. The parasol cell and midget cells have been moved out of position to better illustrate their dendritic morphology and the polygons indicate where the cells are actually located in relation to one another. Arrows indicate axons. 

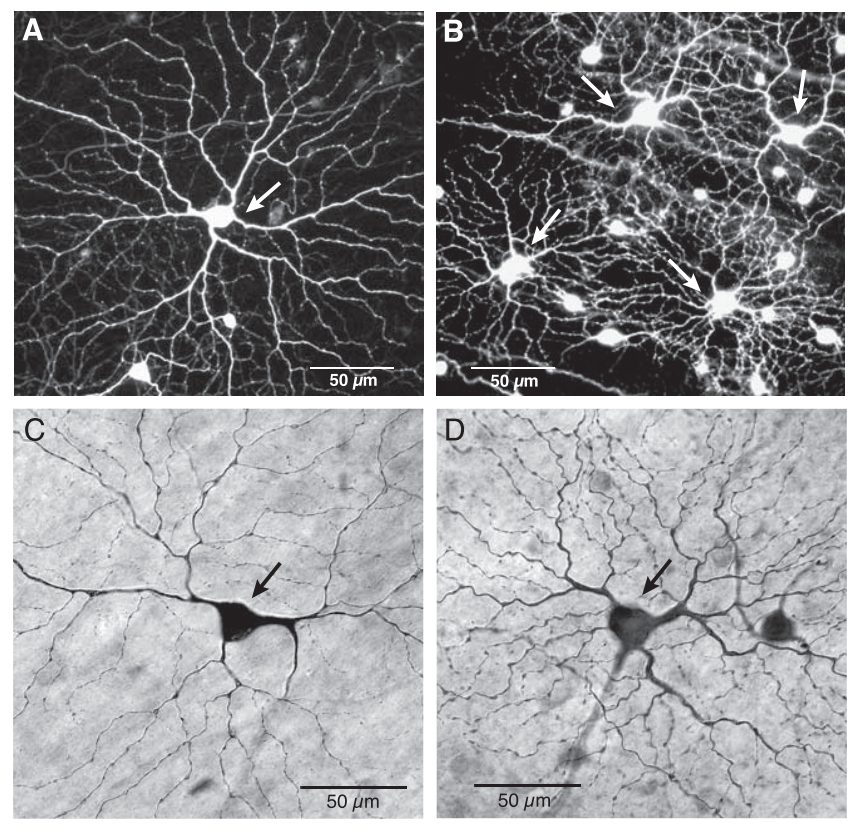

Smooth

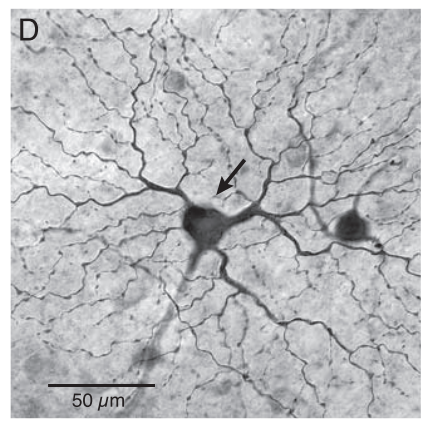

Parasol

Figure 3. Comparison of smooth and parasol dendritic morphology after in vitro photostaining and HRP histochemistry. $A$, Confocal image of a smooth cell retrogradely tracer labeled from injections of biotinylated rhodamine dextran in the superior colliculus and photostained in the in vitro retina. $\boldsymbol{B}$, In vitro image of a group of parasol cells retrogradely tracer labeled from tracer injections in the LGN and photostained in vitro. C, Photomicrograph of a peripheral smooth cell tracer labeled and photostained as described in $A$ and following retina fixation and HRP histochemistry. $\boldsymbol{D}$, Photomicrograph of a peripheral parasol cell tracer labeled as described in $\boldsymbol{B}$ and following retina fixation and HRP histochemistry. Both smooth and parasol cells are narrowly monostratified and show a simple radiate dendritic branching pattern; smooth cells show fewer branches and larger dendritic tree diameters. Arrows in $\boldsymbol{A}-\boldsymbol{D}$ indicate cell bodies.

posure causes a breakdown and dispersal of the aggregated fluorophore leading to the development of intense intracellular fluorescence throughout the dendritic tree. As the rhodamine is also tagged with biotin, subsequent HRP histochemistry can be used to create a permanent reaction product in fixed tissue. In the present study smooth ganglion cells retrogradely photostained by rhodamine-dextran were visualized under epiillumination with a green filter block (excitation filter $545 \mathrm{~nm}$; barrier filter $590 \mathrm{~nm}$ ) and targeted for intracellular recording using a $40 \times$ waterimmersion objective and borosilicate glass microelectrodes filled with a solution of $2-3 \%$ Neurobiotin (Vector Laboratories) and 1-2\% pyranine (Invitrogen) in $1.0 \mathrm{M}$ potassium acetate. Electrode impedances ranged from 300 to $450 \mathrm{M} \Omega$.

Data acquisition and analysis. Intracellular voltage responses recorded from smooth cells were both amplified (Axoprobe-1A; Molecular Devices) and digitized at a sampling rate of up to $10 \mathrm{kHz}$ and averaged over multiple stimulus cycles. The fundamental (F1) and second harmonic (F2) amplitudes and phases of the responses were calculated using a digital Fourier transform. F2 values are only plotted if there was clear evidence of frequency doubling in the histograms and if the calculated F2 was greater than the calculated F1 to contrast reversing gratings. Spatial frequency tuning curves for the F1 and F2 components were fit, respectively, to a difference-of-Gaussians (DoG) and Gaussian model of the receptive field that incorporates both the amplitude and phase of the neural response exactly as was described by Crook et al. (2008). We defined receptive field diameter as 3 times the DoG or Gaussian calculated Gaussian radius $(\mu \mathrm{m})$ as we did in the companion study to most closely match dendritic tree diameter as discussed in the companion study and previously (Peichl and Wässle, 1979, 1983; Lee, 1999). Response versus contrast response functions for the first harmonics were fit with a Naka and Rushton saturation function:

$$
Y=a x /(b+x),
$$

where $a$ is the maximal response in impulses per second; $x$, the Michelson contrast; and $b$, the semisaturation constant (the contrast at which response amplitude is half the maximal response). Such curves are characterized by their percentage contrast gain, $a / b$.

Temporal transfer functions plot the vector average of normalized fundamental amplitude (F1/peak F1) and phase versus temporal frequency. The $\mathrm{F} 1$ phase was found to be an approximately linear function (see Fig. 11C) of the temporal frequency and its slope (cycles/Hz) was used as a measure of the cell's visual latency (Frishman et al., 1987).

Visual stimuli. The apparatus and methods used for visual stimulation were identical to those described by Crook et al. (2008) with the following differences: (1) the temporal sensitivity of cells was investigated using sine waves (50 and $100 \%$ contrast) of increasing temporal frequency ranging from 0.61 to $78.1 \mathrm{~Hz}$ generated with the 4-channel LED stimulator and presented in a full field; (2) cone-isolating stimuli were used to determine the specific cone inputs and weights to the receptive field. Cone-isolating stimuli were obtained by the method of silent substitution and were based on the cone absorption spectra for the macaque monkey (Baylor et al., 1987) and the measured intensity spectrum generated by each of the three-color guns. Briefly, two lights of differing spectral composition are alternated and their relative radiances adjusted so that the alternation between the pair of lights will give rise to a modulated response in one but not the other (the silent) cone type (Estévez and Spekreijse, 1982). The stimulus contrast was matched at $79 \%$ for the $\mathrm{S}$-cone -isolating and $(\mathrm{L}+\mathrm{M})$-cone-isolating stimuli and presented in a $2000 \mu \mathrm{m}$ spot as a square wave modulated at $2 \mathrm{~Hz}$. To determine the relative $\mathrm{L}$ - versus $\mathrm{M}$-cone input strength to a ganglion cell receptive field a protocol, described in detail previously (Dacey et al., 2000; Diller et al., 2004) was used that systematically varied the sign and depth of L- and $\mathrm{M}$-cone modulation around an equivalent mean quantal catch for all three cone types. The amplitude of the sinusoidal modulation of each LED was chosen to create a stimulus with a particular L- and M-cone contrast. The contrast seen by each cone type was varied systematically over a set of 13 stimuli. Initially, L- and M-cone contrasts were equal and of the same sign. M-cone contrast decreased, whereas L-cone contrast increased until $\mathrm{M}$-cone contrast was zero (L-cone isolation). M-cone contrast then reversed sign (equivalent to a $180^{\circ}$ phase shift) and increased while L-cone contrast decreased to zero (M-cone isolation). Finally, the two cone contrasts returned to the same sign and in the last stimulus again had equal contrast (see Fig. $10 E, F$ ). For a cell that only received $\mathrm{L}$ - or $\mathrm{M}$-cone input, responses would fall, respectively, along the upper or lower dotted traces in Figure 10, $C$ and D. Responses from a cell that summed L- and M-cone inputs would fall in between these traces with its minimum response reflecting the relative $\mathrm{L}$ - versus $\mathrm{M}$-cone input ratio. The relative strengths were calculated by fitting the responses with a weighted sum of L- and M-cone inputs:

$$
\text { Response amplitude }=W_{\mathrm{L}} L_{\mathrm{c}}+W_{\mathrm{M}} M_{\mathrm{c}} \text {, }
$$

where $W_{\mathrm{L}}$ and $W_{\mathrm{M}}$ are the weights of the $\mathrm{L}$ - and $\mathrm{M}$-cone inputs, and $L_{\mathrm{c}}$ and $M_{\mathrm{c}}$ are the $\mathrm{L}$ - and $\mathrm{M}$-cone contrasts of the stimulus.

Histology. All histological procedures for staining and preserving retinal ganglion cell morphology and visualizing tracer in serial sections through central recording sites were as described in the companion study (Crook et al., 2008).

Parasol cell physiology. The physiological data for parasol cells used for the comparison with smooth cells in this study derives from the results reported in the companion study (Crook et al., 2008). We briefly highlight a few distinct differences between the recording methods used in that study and those used here. First, parasol cells were selectively targeted by their distinctive cell body shape and large size under IR-DIC optics for loose cell-attached extracellular recordings and were not identified by dendritic morphology as was the case for the smooth cells considered here. In the companion paper we present evidence that all of our recordings were from parasol cells. Second, the parasol cell data were derived from extracellular loose-patch electrode recordings (voltage clamp set at $0 \mathrm{mV}$ ) while smooth cells were recorded intracellularly with high impedance sharp microelectrodes. Compared with extracellular recording, the intracellular method was more difficult and gave rise to 
much more variability in the quality of recordings as the resting membrane potential in many cases was disturbed by intracellular penetration. Finally the stimulus was presented through a $10 \times$ objective (with greater optical quality but a smaller stimulus field) for the parasol recordings and through a $4 \times$ objective for the smooth cells, limiting optical quality for stimuli above 5 cpd (Packer et al., 2001).

\section{Results}

The present results are related conceptually and methodologically to a companion paper that reexamines receptive field spatial nonlinearity and central projections of the parasol ganglion cell type of macaque retina (Crook et al., 2008). In that study we found that the magnocellular LGNprojecting parasol ganglion cells also project to the superior colliculus, have a Y-type receptive field and are comparable to the well studied alpha-Y cell of the cat's retina. Tracer injections into the colliculus also revealed a number of other morphologically distinct ganglion cell populations. One group of cells appeared to form a pair of types stratified on either side of the center of the inner plexiform layer (IPL) and we called these cells the inner and outer smooth monostratified cells (Dacey, 2004). We then reexamined the results of tracer injections into the LGN and observed smooth cells in clusters of retrogradely labeled parasol and midget cells that were difficult to easily distinguish because of their relatively lower density and apparent dendritic costratification with parasol cells. We thus sought to characterize the smooth cells both anatomically and physiologically in relation to the parasol cells. Our anatomical data thus derive from cells retrogradely labeled from tracer injections into either the LGN or the superior colliculus. The description of smooth cell physiological properties however derives exclusively from cells identified in vitro after retrograde photostaining and morphological identification from tracer injections placed in the superior colliculus.

\section{Identification of smooth cells from retrograde photostaining} For both LGN and superior colliculus tracer injections the boundaries of each structure were mapped physiologically by recording multiunit activity in response to full field light flashes; multiple tracer injections were made through the depth of the visually responsive zone. Smooth cells were observed in 14 of 15 animals (20 of 30 retinas) after tracer injections confined to the LGN and in all 7 animals (12 of 13 retinas) after injections confined to the superior colliculus. Serial $80 \mu \mathrm{m}$ sections through the brainstem were studied in all cases to confirm that tracer injections were confined to the target structure. Reconstruction of a bilateral colliculus injection is shown in the companion study (Crook et al., 2008); we found no evidence for intrusion of injec-
C
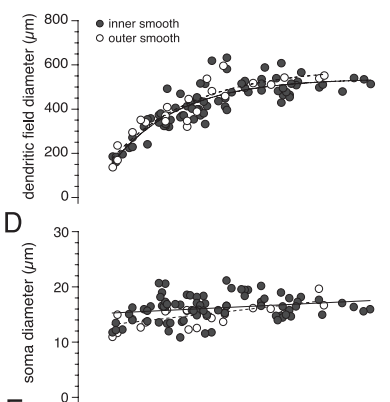

E

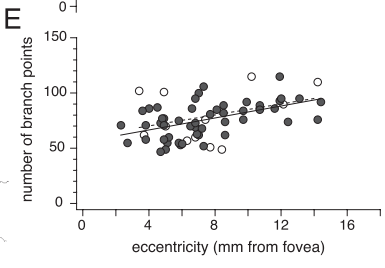

inner parasol

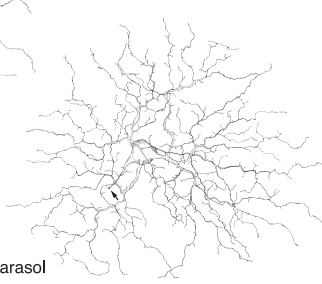

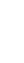

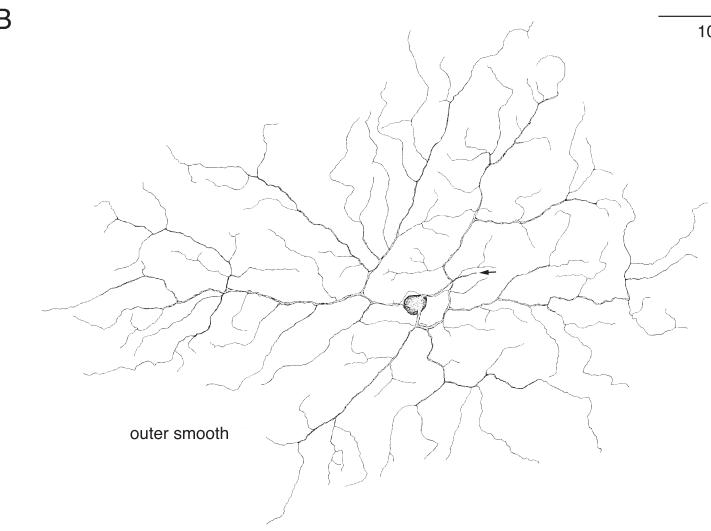

$100 \mu \mathrm{m}$

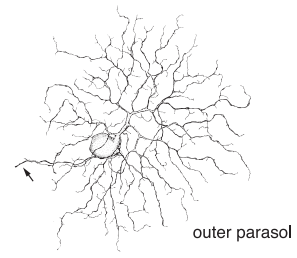

Figure 4. Morphology of inner and outer smooth cells and parasol cells. $A$, Inner smooth cell (left) and inner parasol cell (right) diameter $=213 \mu \mathrm{m}$; retinal eccentricity $\sim 8 \mathrm{~mm}$ for both cells). $\boldsymbol{B}$, Outer smooth and parasol cells (smooth cell soma diameter $=$ $16 \mu \mathrm{m}$, dendritic field diameter $=393 \mu \mathrm{m}$; parasol cell soma diameter $=20 \mu \mathrm{m}$, dendritic field diameter $=171 \mu \mathrm{m} ; 5-6 \mathrm{~mm}$ (solid circles; mean $\pm S D=423 \pm 105 \mu \mathrm{m} ; n=80$ ) and outer smooth cells (open circles; mean $\pm S D=405 \pm 127 \mu \mathrm{m} ; n=$ . Solid and dotted lines are fits to the data for the inner and outer cells respectively of $D=D_{\operatorname{MAX}}(1-\exp (-x))$, where $D$ is

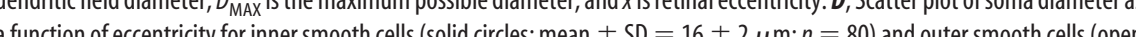
circles; mean $\pm S D=15 \pm 2 \mu \mathrm{m} ; n=22)$. $E$, Scatter plot of the number of branch points as a function of eccentricity for inner smooth cells (solid circles; mean $\pm S D=76 \pm 16 ; n=51$ ) and outer smooth cells (open circles; mean $\pm S D=79 \pm 24 ; n=$ 12). Solid and dotted lines in $\boldsymbol{D}$ and $\boldsymbol{E}$ are linear fits to the data for inner and outer cells respectively.

tion sites in the LGN or pretectum in collicular-injected cases. For LGN cases reconstructions were also made (Fig. $1 A, B$ ) and we found no evidence that these injections intruded on the superior colliculus or pretectal area. Even when multiple injections were made into the LGN, typically only a relatively small subset of axons were clearly retrogradely labeled in the optic tract (Fig. $1 \mathrm{~A}$, bottom, arrows) and ganglion cell staining was restricted to a few small patches of retina. Our conclusion that the smooth cells project to the colliculus derived from the retrograde tracing method appears strong since there is no chance of hitting retinal "fibers-of-passage" that extend caudally beyond the colliculus. In contrast we cannot eliminate the possibility that for the LGN injections retinal axons destined to terminate in the superior colliculus or pretectum were interrupted. However since the retro- 


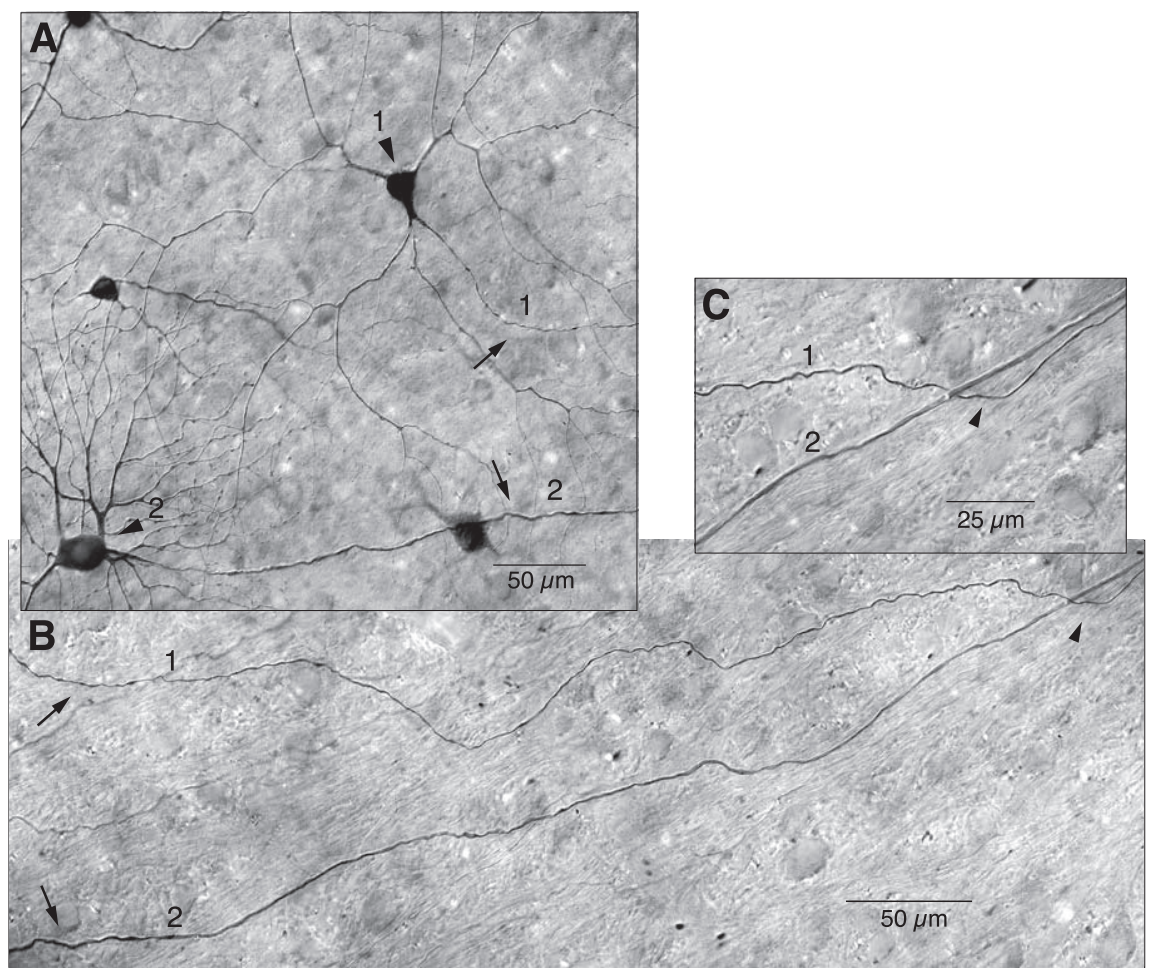

Figure 5. Smooth cells have intraretinal axons that are about half the diameter of parasol cell axons. $\boldsymbol{A}$, Photomicrograph of a smooth cell (1) and a neighboring parasol cell (2). Arrowheads indicate cell bodies. Axons are indicated by arrows and are labeled 1 and 2 for cells 1 and 2 respectively. The complete dendritic morphology of these two cells is illustrated in Figure 7. B, Course of intraretinal axons from both cells extending toward the optic disc. Arrows indicate the same locations shown in $\boldsymbol{A}$. Measurements were made by enlarging light micrographs of the axons and measuring the width of each axon at regular intervals along the $\sim 450$ $\mu \mathrm{m}$ of axon length shown in photo. Parasol axon mean diameter $\pm \mathrm{SD}=1.94 \pm 0.33 \mu \mathrm{m}$; smooth cell axon mean diameter \pm $S D=1.06 \pm 0.22 \mu \mathrm{m} ; n=50$ samples for both axons. Arrowhead indicates area shown at higher magnification in C. C, Magnification of the smooth (1) and parasol (2) axons as they cross one another; note the obviously finer diameter of the smooth cell axon.

grade labeling of smooth cells from many LGN injection cases was reliable and since smooth cells were observed in patches of retrogradely labeled parasol, midget, and small bistratified cells (as for example shown in Fig. 2), ganglion cell types with well established projections to the LGN, the parsimonious hypothesis that the smooth cells also project to the LGN appears strong and is also consistent with their physiological profile as considered further below.

Smooth cells were clearly identified by their larger dendritic trees compared with neighboring photostained parasol and midget cells after LGN tracer injections (Fig. 2). Retrograde photostaining had the advantage of revealing the complete dendritic morphology of a large number of cells that were retrogradely labeled at a single, restricted retinal location. A low magnification view of one such LGN-projecting photostained ganglion cell cluster reveals a complex picture of diverse ganglion cell types (Fig. 2A) that includes midget, parasol, smooth, and other cell types. Sorting of the dendritic trees in this cluster reveals two neighboring smooth cells (thin arrows; cells 1 and 3) with large dendritic trees that costratify and interdigitate and overlap the dendritic field of an inner parasol cell (thick arrow; cell 2). Nearby inner and outer midget cells are also photostained (arrowheads; cells 4 and 5), along with two other ganglion cell types (a "broad thorny" cell and a melanopsin-containing cell; asterisks, not numbered) previously shown to project to the LGN but whose dendritic trees have not been brought into focus (Dacey et al., 2003, 2005). Detailed tracings and high-magnification micrographs further illustrate the qualitative morphological differences among the nearby midget, parasol, and smooth cells (Fig.
$2 B, C)$. The two smooth cells have smaller cell bodies but larger and more sparsely branching dendritic trees than the parasol cell. However the dendrites of these two cells also appear to costratify with the inner parasol within the IPL. In Figure $2 \mathrm{~B}$ a small field of dendrites that includes both inner smooth cells and the inner parasol cell is shown at higher magnification; in regions where the dendrites are adjacent or crossover one another the processes appear to occupy precisely the same depth near the center of the IPL. In the following results we provide a more detailed comparison of smooth cell and parasol cell dendritic morphology acquired from both LGN and collicular retrograde photostaining.

The smooth cells showed relatively thick primary dendrites and a simple radiate branching structure with no spines and few short branchlets. By comparison parasol cells at the same retinal locations have more highly branched dendrites and a moderate density of spine like structures and short branchlets; these distinctions can be clearly observed after photostaining in the in vitro retina (Fig. $3 A, B$ ) and permitted subsequent selective targeting of the smooth cells for intracellular recording. After tissue fixation and HRP histochemistry (Fig. 3C,D) these morphological differences were preserved and we used this material to quantify dendritic stratification and field size in relation to the parasol cells.

\section{Smooth cells comprise separate inner and outer stratifying populations}

Smooth cell dendrites were narrowly stratified near the center of the IPL in either the outer-OFF or the inner-ON subdivision and thus formed a pair of cell types similar to that of the inner and outer parasol cells (Fig. 4A,B). At a given eccentricity inner smooth cells tended to show slightly larger-diameter cell bodies and dendritic fields than outer smooth cells [inner cell body diameter, $16 \pm 2 \mu \mathrm{m}$ (mean $\pm \mathrm{SD} ; n=80)$; outer cell body diameter, $15 \pm 2 \mu \mathrm{m}$ (mean $\pm \mathrm{SD} ; n=22)$; inner dendritic field diameter of $423 \pm 105 \mu \mathrm{m}$ (mean $\pm \mathrm{SD} ; n=80$ ); and outer dendritic field diameter of $405 \pm 127 \mu \mathrm{m}$ (mean $\pm \mathrm{SD} ; n=22)$ ] (Fig. $4 C, D)$. The number of dendritic branch points for inner cells (mean $\pm \mathrm{SD}=76 \pm 16 ; n=51$ ) versus outer cells (mean \pm $\mathrm{SD}=79 \pm 24 ; n=12$ ) were nearly identical for both populations (Fig. 4 E). Similar to other ganglion cell populations, smooth cells showed a clear increase in dendritic field diameter with increasing distance from the fovea. The most central smooth cells observed after retrograde staining were at $\sim 1.5-2.0$ mm eccentricity and showed dendritic field diameters of $\sim 150 \mu \mathrm{m}$; cells in the retinal periphery attained diameters of $\sim 500-600 \mu \mathrm{m}$ (Fig. $4 C$ and see Fig. 6A).

\section{Distinguishing smooth cells from parasol cells}

The average smooth cell soma diameter was toward the large end of the range for macaque ganglion cells (Watanabe and Rodieck, 1989; Dacey, 1993b; Rodieck and Watanabe, 1993; Dacey et al., 
2005) $($ mean $\pm \mathrm{SD}=16 \pm 2 \mu \mathrm{m}, n=102)$ but was significantly smaller $(p<0.0003$, unpaired two-tailed $t$ test) than that of parasol cells (mean $\pm \mathrm{SD}=17 \pm 3 \mu \mathrm{m}$, $n=155)$. The smooth cell intraretinal axon diameter also appeared to be relatively large compared with other smallbodied collicular projecting ganglion cells but significantly smaller ( $p<0.0001$, unpaired two-tailed $t$ test) than that of neighboring parasol cells (Fig. 5A-C). To quantify this at the light microscopic level we measured axon diameter for a neighboring parasol and smooth cell pair at 50 locations along a $450 \mu \mathrm{m}$ length of each axon as it extended toward the optic disc in the optic fiber layer (parasol: $1.94 \pm 0.33 \mu \mathrm{m}$; smooth: $1.06 \pm 0.22 \mu \mathrm{m}$; mean $\pm \mathrm{SD} ; n=$ 50 samples for both axons). The major distinction between smooth and parasol cells was the larger dendritic field diameter for the smooth cells. At any given eccentricity smooth cell dendritic trees were consistently $\sim 1.5-3$ times larger $(p<0.0001$, unpaired two-tailed $t$ test) than parasol cells ( $419 \pm 110 \mu \mathrm{m}$, mean $\pm \mathrm{SD} ; n=102$; $209 \pm 70 \mu \mathrm{m}$, mean $\pm \mathrm{SD} ; n=348$, respectively) (Figs. 4, 6B). Fits to the data (Fig. $6 B$ ) suggest however that there is a systematic change in the dendritic field size ratio between the smooth and parasol cells as a function of eccentricity with the parasol cell decreasing in field size at a greater rate than the smooth cells as the fovea is approached. In the far periphery, between 13 and $16 \mathrm{~mm}$ eccentricity the ratio of smooth to parasol field size is $1.7: 1$ but this increases steadily to reach a 3:1 ratio by $2 \mathrm{~mm}$ eccentricity. Given a similar and constant dendritic coverage for the smooth and parasol cell populations (as discussed below) this suggests that the parasol cells would increase in number relative to the smooth cells from $\sim 4: 1$ in the far periphery to $\sim 9: 1$ in the central retina.

\section{Smooth cells and parasol cells show precise dendritic costratification}

As illustrated in Figure 2, overlapping dendritic trees of retrogradely labeled smooth and parasol cells appeared to costratify within the IPL. We attempted to quantify the relative depth of stratification for four inner and two outer smooth-parasol cell pairs by sampling many dendritic locations and measuring depth of best focus with the light microscope at each sample point relative to the inner and outer IPL borders (Fig. 7A). We found that the inner and outer smooth and parasol cells were narrowly costratified over a $\sim 1-2 \mu \mathrm{m}$ depth within the IPL. Moreover, at a given retinal point a smooth dendrite might appear on the inner side of an overlapping parasol dendrite and at a nearby location the same two dendrites could reverse position (Fig. $7 A-C$ ). The cells thus appeared to be intertwined across the same narrow depth for both inner and outer strata. For the four inner cell pairs, smooth cell mean percentage depth was $61 \pm 5 \%$ (mean \pm SD, $n=61$ ) and parasol cell mean depth was $62 \pm 5 \%$ (mean \pm SD; $n=61)$. For the two outer cell pairs, smooth cell mean depth was $37 \pm 5 \%($ mean $\pm \mathrm{SD}, n=24)$, and parasol cell mean depth was $36 \pm 4 \%($ mean $\pm \mathrm{SD}, n=24)$. Both smooth and parasol inner and outer dendrites substantially overlapped. We also compared measurements of smooth cell dendritic stratification from a larger sample of smooth cells (68 inner and 16 outer cells) with previously published measurements for a larger sample of parasol cells made in a similar manner (Watanabe and Rodieck, 1989) and found that the same pattern of smooth-parasol costratification emerged. In contrast, midget ganglion cell dendritic arbors (Figs. 2, 7D) (Watanabe and Rodieck, 1989) are positioned toward the outer and inner IPL borders relative to the smooth and parasol cells. In addition, a survey of other LGN and collicular projecting ganglion cell morphology does not reveal any other types that share the smooth-parasol position in the IPL (Dacey, 2004). It thus appears that the combination of depth of IPL stratification together with dendritic field size can be used as a morphological signature to distinguish smooth cells from all other macaque ganglion cell types thus far identified.

\section{Smooth cells form independent spatial mosaics}

Anatomically distinct ganglion cell populations form independent spatial arrays in which the cell bodies are nonrandomly placed and the dendritic trees tile the retinal surface with minimal overlap. To maintain a constant tiling or coverage with increasing distance from central retina, ganglion cell dendritic field area increases in proportion to decreasing cell density (Wässle and Riemann, 1978; Wässle et al., 1981; Dacey, 1989; Vaney, 1994). Because the smooth cells are costratified with the parasol cells we wanted to confirm that this cell group represented an independent ganglion cell mosaic rather than some morphological variant of the parasol cell. We were able to examine in part the local spatial densities and dendritic tree arrangements of smooth cells at retinal locations where it appeared that the dendritic tree of 

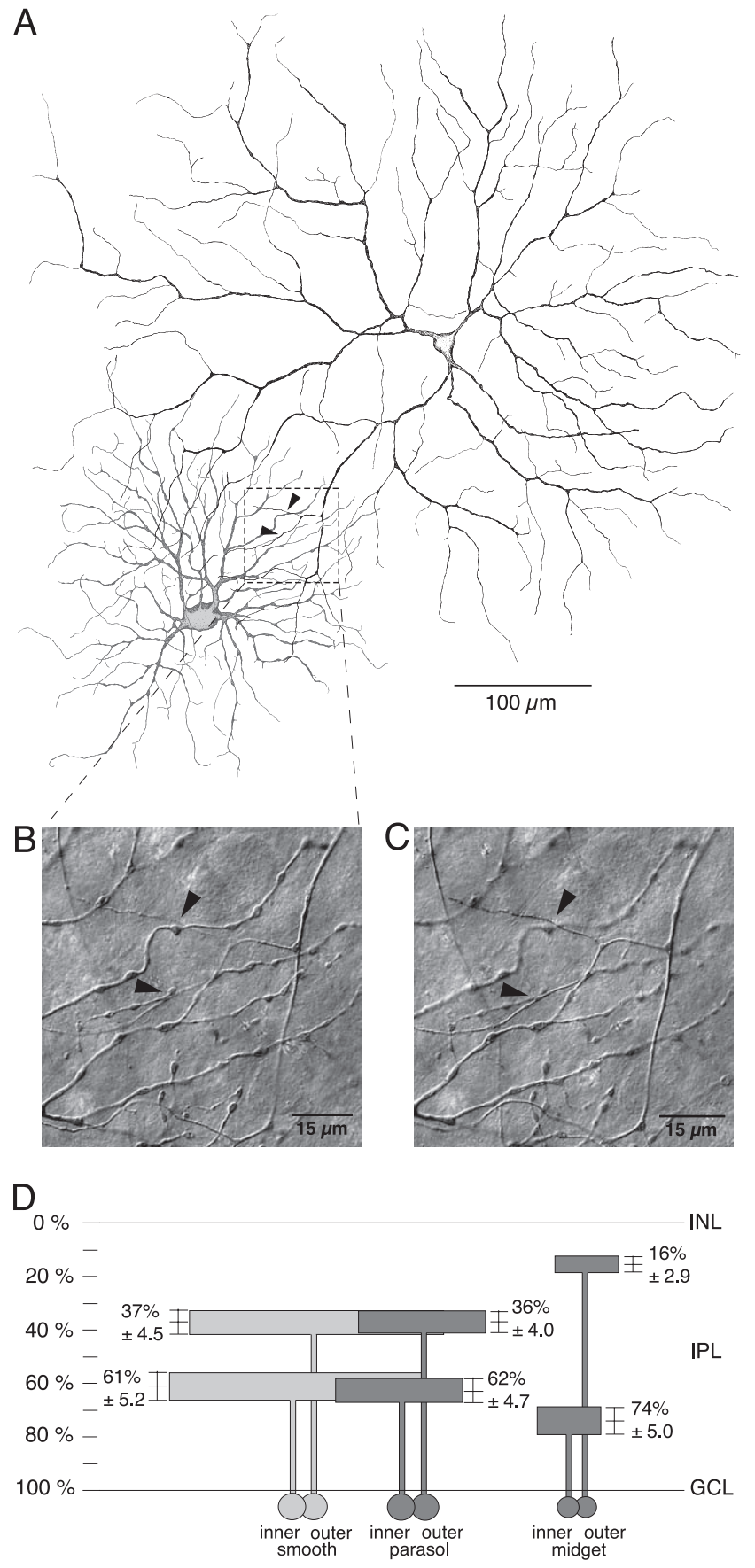

Figure 7. Smooth and parasol dendritic trees costratify within the IPL. $\boldsymbol{A}$, Tracings of an inner smooth and inner parasol cell with overlapping dendritic fields. Area in black box is shown in enlarged view in $\boldsymbol{B}$ and $\boldsymbol{C}$ with the arrowheads indicating crossover points of smooth and parasol cell dendrites. $\boldsymbol{B}$, Photomicrograph of the boxed area in $\boldsymbol{A}$ with the focus on the parasol cell dendrites indicated by the arrowheads. $\boldsymbol{C}$, Photomicrograph of the boxed area in $\boldsymbol{A}$ with the focus shifted to the smooth cell dendrites indicated by the arrowheads, $\sim 1.5 \mu \mathrm{m}$ closer to the middle of the IPL. $\boldsymbol{D}$, Dendritic stratification plotted as mean percentage depth \pm SD as determined by measuring depth at 61 locations in the overlapping dendritic fields of four pairs of inner smooth and parasol cells and at 24 locations in the overlapping dendritic fields of two pairs of outer smooth and parasol cells in whole-mount retina. Mean stratification depth for midget cells is taken from previous measurements made in the same way (Watanabe and Rodieck, 1989) (GCL, ganglion cell layer; IPL, inner plexiform layer; INL, inner nuclear layer).

every inner or outer smooth cell was fully stained (Fig. 8A,B). Since smooth cell staining depended on retrograde transport we could not be certain that every cell in a local patch had been labeled. However certain features argue strongly that in some instances all neighboring cells were stained. For the two smooth cell "patches" illustrated in Figure 8 the cell bodies appeared regularly spaced, a well documented and distinctive feature of independent retinal cell mosaics (Rockhill et al., 2000). More importantly the neighboring dendritic trees neatly interdigitated to fill space evenly. The territorial organization created by precise interdigitation of neighboring dendritic trees is a previously characterized feature for both primate and other mammalian ganglion cell populations (Wässle et al., 1981; Dacey, 1989, 1993a; Vaney, 1994; Stein et al., 1996; Berson et al., 1998). For one patch of 8 cells at $7-8 \mathrm{~mm}$ eccentricity (Fig. $7 A$ ) a cell density of 9 cells $/ \mathrm{mm}^{2}$ was multiplied by the mean dendritic field area (mean area $\pm \mathrm{SD}=0.190 \pm 0.077 \mathrm{~mm}^{2}, n=8$ ) to give a coverage factor of 1.7. This is similar to that of the parasol cells (Dacey and Brace, 1992) and many other ganglion cell types of the mammalian retina (Wässle et al., 1981; Dacey, 1993a,b; Stein et al., 1996). If we assume that the patches illustrated in Figure 8 reflect the mosaic of smooth cells then we can use this pattern to estimate total smooth ganglion cell density. Given that the local density of $\sim 9$ cells $/ \mathrm{mm}^{2}$ for the patch of inner smooth cells shown in Figure $8 \mathrm{~A}$ is approximately matched by the outer smooth cells (and assuming a total ganglion cell density at this location of $\sim 625 \mathrm{cells} / \mathrm{mm}^{2}$ (Wässle et al., 1989) the inner and outer smooth cells together would comprise $\sim 3 \%$ of the total ganglion cells in the retinal periphery. At similar eccentricities the presumed parasol cells may comprise $\sim 7-10 \%$ of the total ganglion cells (Silveira and Perry, 1991).

\section{Smooth versus parasol cell receptive field properties}

\section{Receptive field size}

Smooth cells were targeted for intracellular recording under direct visual control by their distinctive soma size and dendritic morphology observed in vitro after retrograde photostaining from tracer injection made into the superior colliculus in 4 animals. We recorded from 43 morphologically identified smooth cells in the retinal periphery. High contrast sinusoidally modulated spot and annular stimuli centered over the receptive field revealed clear center-surround receptive field organization and permitted an easy correlation of dendritic stratification with $\mathrm{ON}$ vs OFF center receptive fields. All inner stratifying cells showed depolarizing $\mathrm{ON}$ responses to small spots $(\sim 200 \mu \mathrm{m}$ diameter $)$ centered on the receptive field and either mixed ON-OFF or OFF responses to annular stimuli (Fig. 9A). Outer stratifying cells showed OFF center and ON surround responses to the same stimuli. Spatial frequency tuning was measured with gratings modulated sinusoidally at $50 \%$ contrast and drifted at $10.5 \mathrm{~Hz}$ (Fig. 9B) which, as will be shown shortly, is near the peak of the temporal frequency response for these cells. The peak spike discharge rate for such stimuli was $50 \pm 35$ spikes/s (mean \pm SD, $n=16$ ). The majority of cells exhibited bandpass spatial frequency tuning well fit by a DoG center-surround receptive field model (Enroth-Cugell et al., 1983) with the fit parameters for ON and OFF cells listed in Table 1 . Note that as a consequence of insufficient sampling at the lowest spatial frequencies the surround sizes and strengths were most likely underestimated. Full center size was taken as $3 \times$ the Gaussian radius (Peichl and Wässle, 1983; Lee, 1999; Crook et al., 2008) and was measured for a sample of 27 smooth cells. For a sample of smooth cells from the same eccentricity, that is $>9 \mathrm{~mm}$ from the fovea, the receptive field center size corresponded well with dendritic field diameters $>9 \mathrm{~mm}$ from the fovea (Fig. 9C) (dendritic tree diameter: mean $\pm \mathrm{SD}=513 \pm 38 \mu \mathrm{m}, n=32$; receptive field diameter: mean $\pm \mathrm{SD}=574 \pm 123 \mu \mathrm{m}, n=28$ ). We cannot directly 
compare smooth cell center receptive field diameters with parasol cells (receptive field diameter: mean $\pm \mathrm{SD}=176 \pm 60$ $\mu \mathrm{m} ; n=113$ ) (Crook et al., 2008) as all smooth cell recordings were taken from far peripheral retina while the majority of parasol recordings were from central to mid-peripheral retina. However for each cell type, the diameter of the dendritic tree corresponds well to the diameter of the receptive field center (Fig. 9C,D). Thus dendritic field diameters collected across eccentricities for both cell classes (Fig. 6) (dendritic tree diameter: smooth cell mean $\pm \mathrm{SD}=419 \pm 110 \mu \mathrm{m}, n=102$; parasol cells mean $\pm \mathrm{SD}=209 \pm 70 \mu \mathrm{m}$, $n=348$ ) indicate smooth cell receptive field diameters should be approximately twice the size of parasol cells in mid peripheral retina.

\section{Cone inputs}

While spatial opponency was evident in the receptive field structure we found no evidence for either red-green (L- vs $\mathrm{M}$-cone antagonism) or blue-yellow (S- vs $\mathrm{L}+\mathrm{M}$-cone antagonism) chromatic opponency. Smooth cells received mixed summed input from L- and M-cones (Fig. $10 \mathrm{~A}$ ). For two cells we systematically varied the L- and M-cone stimulus contrast (Fig. 10C,D) and fit the data with a simple linear model in which stimulus cone contrast was proportional to response amplitude to estimate the relative $\mathrm{L}$ - and M-cone input strength (Dacey et al., 2000). Smooth cells appeared to sum Land $\mathrm{M}$-cone inputs nonselectively with L-cone input being dominant (Fig. 10C,D) as shown previously for parasol cells (Lee et al., 1988; Diller et al., 2004). In response to very high contrast $\mathrm{S}$-cone-isolating stimuli there was no obvious modulation of the membrane potential for three cells tested (Fig. $10 \mathrm{~B}$ ). Nonetheless a small input cannot be ruled out.

\section{Temporal frequency response}

Smooth cells, like parasol cells, show relatively transient light responses to light steps and a bandpass temporal frequency response that peaks at or above $10 \mathrm{~Hz}$ at high stimulus contrasts and moderate photopic levels (Fig. $11 A-C$ ). Comparison of parasol and smooth cell temporal tuning in Figure $11 B$ suggests that the parasol cells may show a peak response and cutoff at slightly higher temporal frequencies than the smooth cells; however, this may not always be the case. There was much overlap between the two relatively small samples (average peak temporal frequency response: smooth cells mean $\pm \mathrm{SD}=13 \pm 5 \mathrm{~Hz}, n=5$; parasol cells mean $\pm \mathrm{SD}=21 \pm 13 \mathrm{~Hz}, n=10 ; p=0.18$, unpaired two-tailed $t$ test) ) and the smooth cell data were taken from highimpedance sharp intracellular recordings with some inevitable variability in the resting membrane potential, whereas the parasol

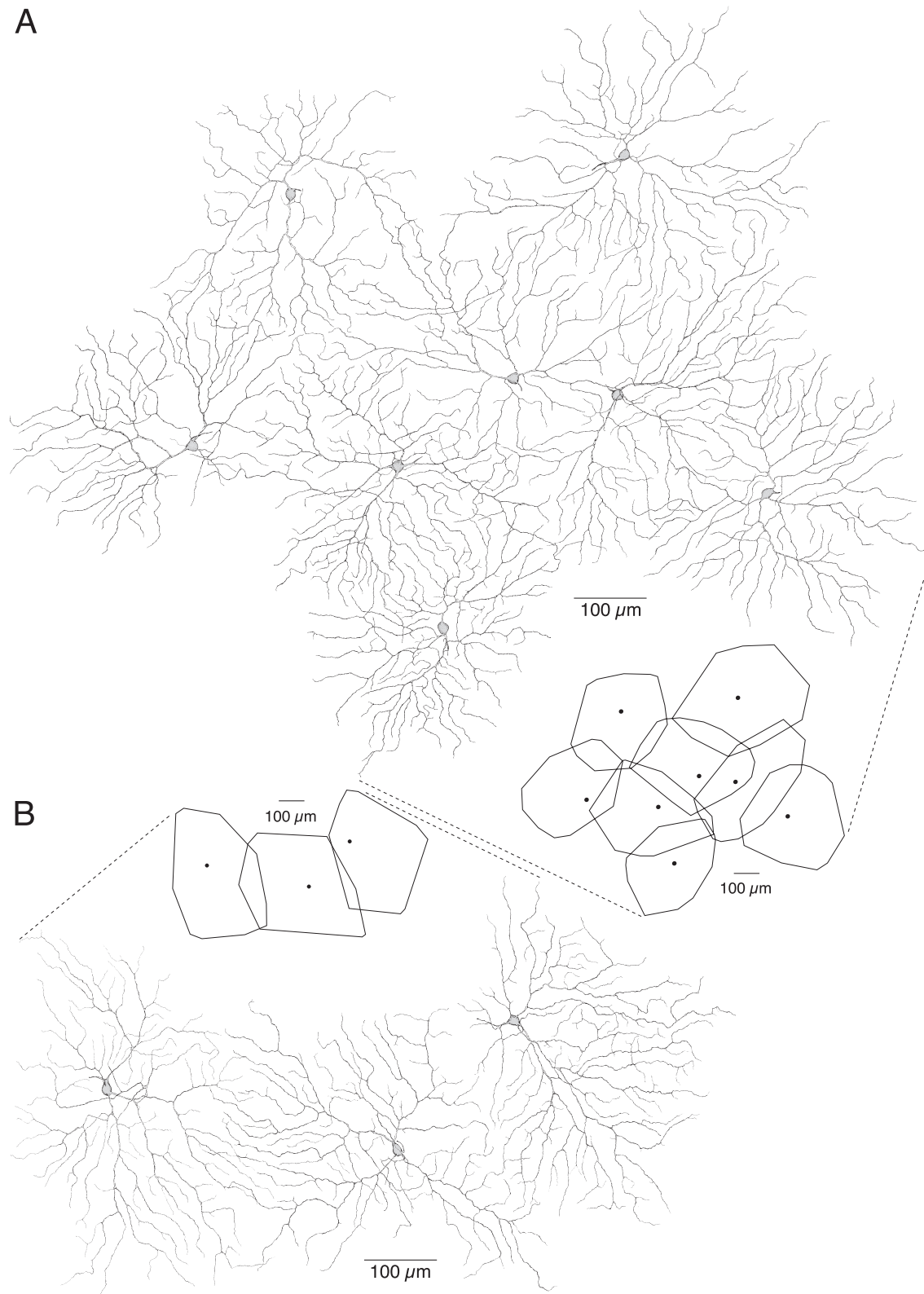

Figure 8. Smooth cells comprise $\sim 3 \%$ of the total ganglion cell population. $A$, Tracings of 8 neighboring inner smooth cells located $\sim 8 \mathrm{~mm}$ from the fovea. Outlines of the cells' dendritic fields are shown at lower right at reduced scale. $\boldsymbol{B}$, Tracings of 3 neighboring inner smooth cells located $\sim 9 \mathrm{~mm}$ from the fovea. Outlines of the cells dendritic fields are shown at reduced scale. A density of $3 \%$ of total ganglion cells was estimated by counting the number of inner cells in an area $7-8 \mathrm{~mm}$ from the fovea ( 9 cells $/ \mathrm{mm}^{2}$ ) and assuming a similar density for outer cells. Total ganglion cell density $\left(625\right.$ cells $\left./ \mathrm{mm}^{2}\right)$ at this eccentricity was taken from Wässle et al. (1989). A coverage factor of 1.7 for inner smooth cells was determined by multiplying a density of 9 cells $/ \mathrm{mm}^{2}$ by the mean dendritic field area at $7-8 \mathrm{~mm}$ eccentricity (mean area $\pm \mathrm{SD}=0.1902 \pm 0.077 \mathrm{~mm}^{2} ; n=8$ ).

cell data were taken from extracellular loose patch recordings. Visual response latencies for ON and OFF smooth cells calculated from the temporal frequency response phase (Fig. 11C) show OFF smooth cells (mean $\pm \mathrm{SD}=38 \pm 1 \mathrm{~ms}, n=2$ ) had a shorter latency than $\mathrm{ON}$ smooth cells (mean $\pm \mathrm{SD}=52 \pm 3 \mathrm{~ms}, n=5$ ). Both ON and OFF smooth cells tended to have longer latencies than parasol cells computed by the same method (parasol OFF mean $\pm \mathrm{SD}=29 \pm 1 \mathrm{~ms}, n=3$; parasol ON mean $\pm \mathrm{SD}=39 \pm$ $5 \mathrm{~ms}, n=7)$. OFF parasol cells also showed shorter latencies than their ON counterparts. Overall our latency estimates were comparable to previous measurements from parasol cells recorded in the intact animal (Lee et al., 1994; Benardete and Kaplan, 1999). 
A

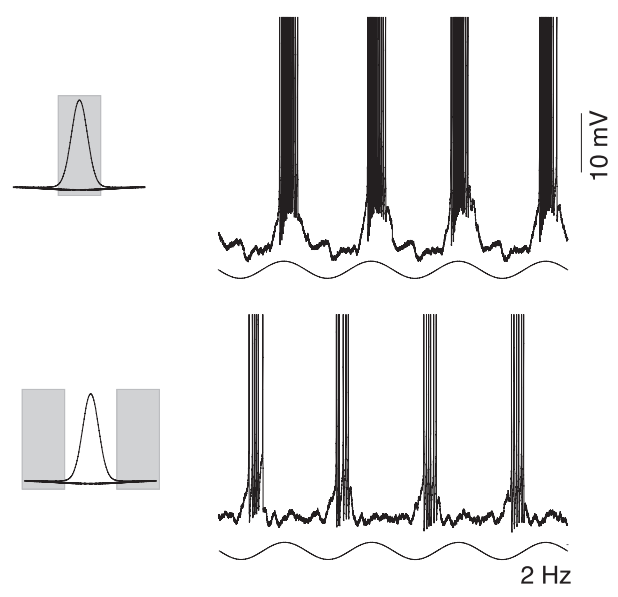

C

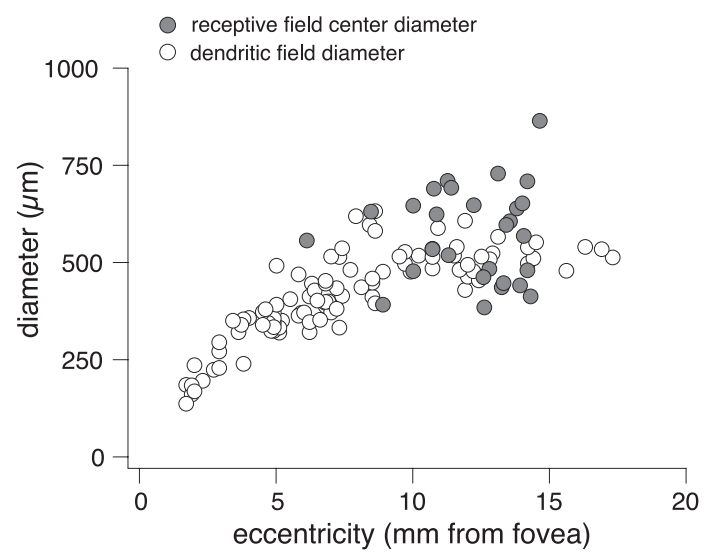

B

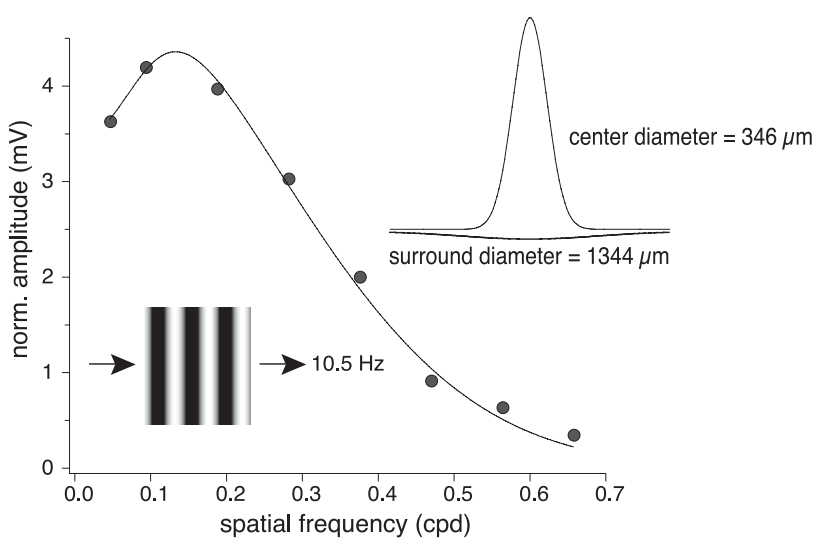

D

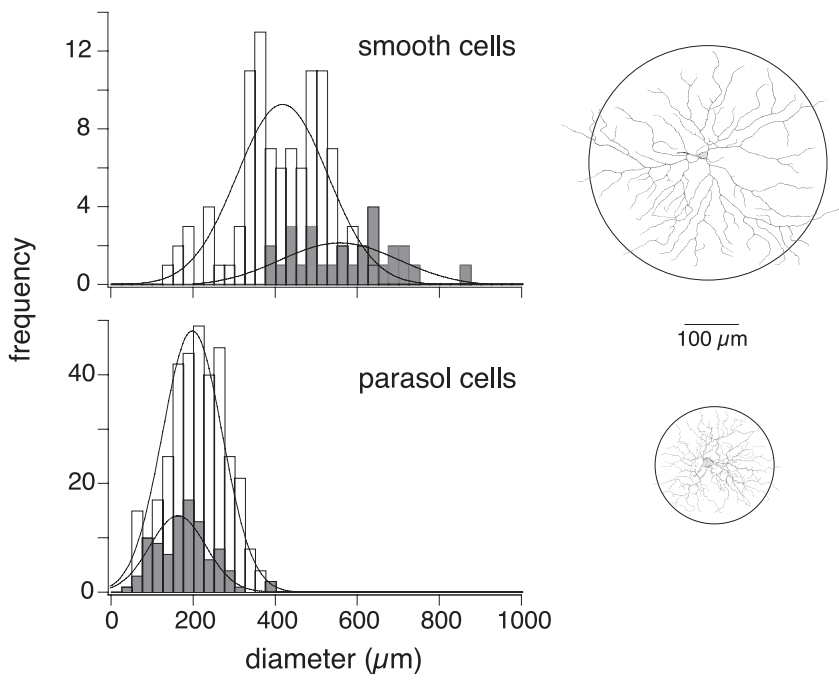

Figure 9. Smooth cells have large receptive fields with center and surround organization. $\boldsymbol{A}$, Center responses were isolated with a $700 \mu \mathrm{m}$ diameter spot (upper trace) and surround with a $700-2000 \mu \mathrm{m}$ diameter annulus (lower trace) and sinusoidally modulated at $2 \mathrm{~Hz}, 100 \%$ contrast. Center and surround responses were $\sim 110$ degrees out of phase. B, Spatial frequency tuning curve for a typical peripheral smooth cell. The first Fourier harmonic (F1) of the membrane potential (mV) to drifting gratings at $10.5 \mathrm{~Hz}, 50 \%$ contrast, plotted as a function of spatial frequency. Solid line is a difference-of-Gaussians receptive field model fit to the data; inset is a 2 dimensional profile of the model fit. The calculated Gaussian radius was multiplied by 3 to estimate the center diameter equivalent to that of a dendritic tree. C, Smooth cell center receptive field diameters (solid circles, $n=27$ ), determined by a Gaussian model fit, and anatomical dendritic field diameter measurements (open circles, $n=102$ ) as a function of eccentricity. $\boldsymbol{D}$, Histograms of dendritic field diameters (open bars, $n=102$ ) and receptive field center diameters (gray bars, $n=27$ ) for smooth cells (upper histogram) and parasol cells (lower histogram) (dendritic field diameters, open bars; $n=348$; receptive field center diameters, gray bars, $n=113$ ). The lines are Gaussian fits to the data. The center receptive field diameter and the dendritic field diameter of smooth cells are approximately twice the size of parasol cells and four times the area as illustrated in the insets.

Table 1. F1 difference of Gaussians and F2 Gaussian fit parameters

\begin{tabular}{lllllll}
\hline & $\begin{array}{l}\text { Gaussian center } \\
(\mu \mathrm{m})\end{array}$ & $\begin{array}{l}\text { Gaussian sur- } \\
\text { round }(\mu \mathrm{m})\end{array}$ & $\begin{array}{l}\text { Center phase } \\
\text { (radians) }\end{array}$ & $\begin{array}{l}\text { Surround phase } \\
\text { (radians) }\end{array}$ & $\begin{array}{l}\text { Center/surround } \\
\text { weight }\end{array}$ & $\begin{array}{l}\text { Center wt. } \\
(\text { spikes/s) }\end{array}$ \\
\hline F1 0N & $187 \pm 37(24)$ & $391 \pm 175(24)$ & $0.03 \pm 0.6(24)$ & $-3.1 \pm 0.6(24)$ & $1.54 \pm 0.54(24)$ & \\
F1 0FF & $203 \pm 35(4)$ & $328 \pm 35(4)$ & $-3.2 \pm 0.3(4)$ & $-0.2 \pm 0.5(4)$ & $3.20 \pm 3.33(3)$ & \\
F2 0N & $42 \pm 8(7)$ & & & & & $94 \pm 76(7)$ \\
F2 0FF & $48 \pm 8(4)$ & & & & $62 \pm 29(4)$ \\
\hline
\end{tabular}

Summary of F1 and F2 spatial tuning curve fitting parameters (mean \pm SD) for ON and OFF smooth ganglion cells. F1 receptive fields were fit using a difference-of-Gaussians model and $\mathrm{F} 2$ receptive fields with a Gaussian model. $n$ values are given in parentheses.

However the faster response time in both smooth and parasol OFF-cells was surprising given the recent suggestion that in primate the ON parasol pathway shows faster overall response kinetics than the OFF pathway (Chichilnisky and Kalmar, 2002). A longer latency for the ON pathways would be predicted given the use of a second messenger cascade by the ON bipolar pathway. Recent recordings from salamander bipolar cells do find OFF bipolar cells to have consistently much shorter response latencies than ON bipolar cells (Burkhardt et al., 2007) and Burkhardt et al., calculates that the delay of the ON pathway in mammals, given a warmer body temperature, would be $\sim 8 \mathrm{~ms}$, roughly consistent with the differences we have observed for the ON versus OFF smooth and parasol cells.

\section{Contrast gain}

We measured contrast sensitivity for 4 smooth cells and 12 parasol cells and found that both types have high contrast sensitivity and show a steep contrast gain function that saturates at relatively low contrast. Figure 12, $A$ and $B$, plots the amplitude of the first Fourier harmonic (F1) response to sinusoidally modulated gratings drifted at $10.5 \mathrm{~Hz}$ at contrasts ranging from 3 to $100 \%$ for four smooth cells. Responses for both smooth and parasol cells increase linearly at low contrasts but compress at contrasts above 
$25 \%$. Smooth cell data are compared with a larger parasol cell dataset from the companion study (Crook et al., 2008) in Figure 12C. These data are well fit by Naka-Rushton saturation functions (see Materials and Methods and Fig. 12C). Such curves can be characterized by the initial slope (contrast gain, $a / b$ ) and both smooth and parasol cells show average contrast gain values with a slope $>2$ (Fig. 12D). Whether the steeper slopes found for some parasol cells reflect either differences in recording methods (extracellular vs intracellular), the relatively small sample of smooth cells, or that parasol cells as a population have higher contrast gain values remains to be determined.

\section{Y-cell signature}

Smooth cells show a Y-cell receptive field signature like that shown for parasol cells in the companion study (Crook et al., 2008). To characterize nonlinearity in receptive field spatial summation we compared the F1 response to sinusoidally modulated drifting gratings with the second Fourier harmonic (F2) response to stationary contrast reversing gratings modulated at the same temporal frequency and contrast (Fig. 13A,C). The F2 and F1 spatial frequency tuning curves cross one another as the F1 response rolls off at low spatial frequencies, reflecting the large receptive field center, and the $\mathrm{F} 2$ response extends to higher spatial frequencies before rolling off. The higher spatial frequency resolution of the F2 component is the major feature of the Y-cell signature (So and Shapley, 1979; Spitzer and Hochstein, 1985; Crook et al., 2008). In addition, at spatial frequencies greater than the F1 peak, the F2 component is insensitive to the spatial position of the stimulus in the receptive field (Fig. 13B). The F2 phase insensitivity is not shown in the Y-cell signature plot. To test F2 spatial phase insensitivity, we calculated mean F1 and F2 responses as a function of spatial phase, in 45 degree intervals, in response to contrast reversing gratings of increasing spatial frequency (Fig. 13B, left). The spatial frequencies used are indicated in Figure 13Ai,ii,iii, iv; the data in Figure 13, $A$ and $B$, are from the same cell. Two cycles of response for each data point are illustrated to the right of each plot in Figure $13 B$ and the location of the stimulus in relation to the receptive field center is indicated in the icons above each voltage trace. At low spatial frequencies there is either no F2 component and a null response when the stimulus is perfectly centered on the cell's receptive field (Fig. $13 B i, 0.047 \mathrm{cpd}$ ), or both the F1 and F2 response amplitude strongly depends on the spatial phase of the stimulus (Fig. 13Bii, $0.282 \mathrm{cpd}$ ). At high spatial frequencies the F2 dominates and is insensitive to the phase of the stimulus (Fig. 13Biii, $0.564 \mathrm{cpd}$; Fig. 13 Biv, $0.846 \mathrm{cpd}$ ). We made $\mathrm{Y}$-cell signature plots and measured phase insensitivity for 17 smooth cells (Fig. 13C) and fit F2 spatial tuning curves with a Gaussian receptive field model (Crook et al., 2008). The average center radius and weights are listed in Table 1 for ON and OFF smooth cells. For peripheral smooth cells on average the spatial resolution limit of the F2 is $\sim 4$ times greater than the F1 (F1 spatial resolution limit mean $\pm \mathrm{SD}=1 \pm 0.2 \mathrm{cpd}$, range $0.69-1.6 \mathrm{cpd} ; \mathrm{F} 2$ spatial resolution limit mean $\pm \mathrm{SD}=5 \pm$ $1 \mathrm{cpd}$, range $2.56-6.25 \mathrm{cpd}$ ). This value is similar to the parasol F2:F1 ratio of 4:1 for a population of parasol cells from all eccentricities ( $n=113$; Crook et al., 2008). However we believe that quantitative comparison of the F2 values obtained for the smooth cells with corresponding data for the parasol cells must be made with caution. The parasol cell F2 measurements were made with loose patch recordings that remained stable for long time periods, and much higher quality optics $(10 \times$ objective) were used with great effort placed on carefully focusing the stimulus on the photoreceptors, permitting us to gather data at the highest spatial
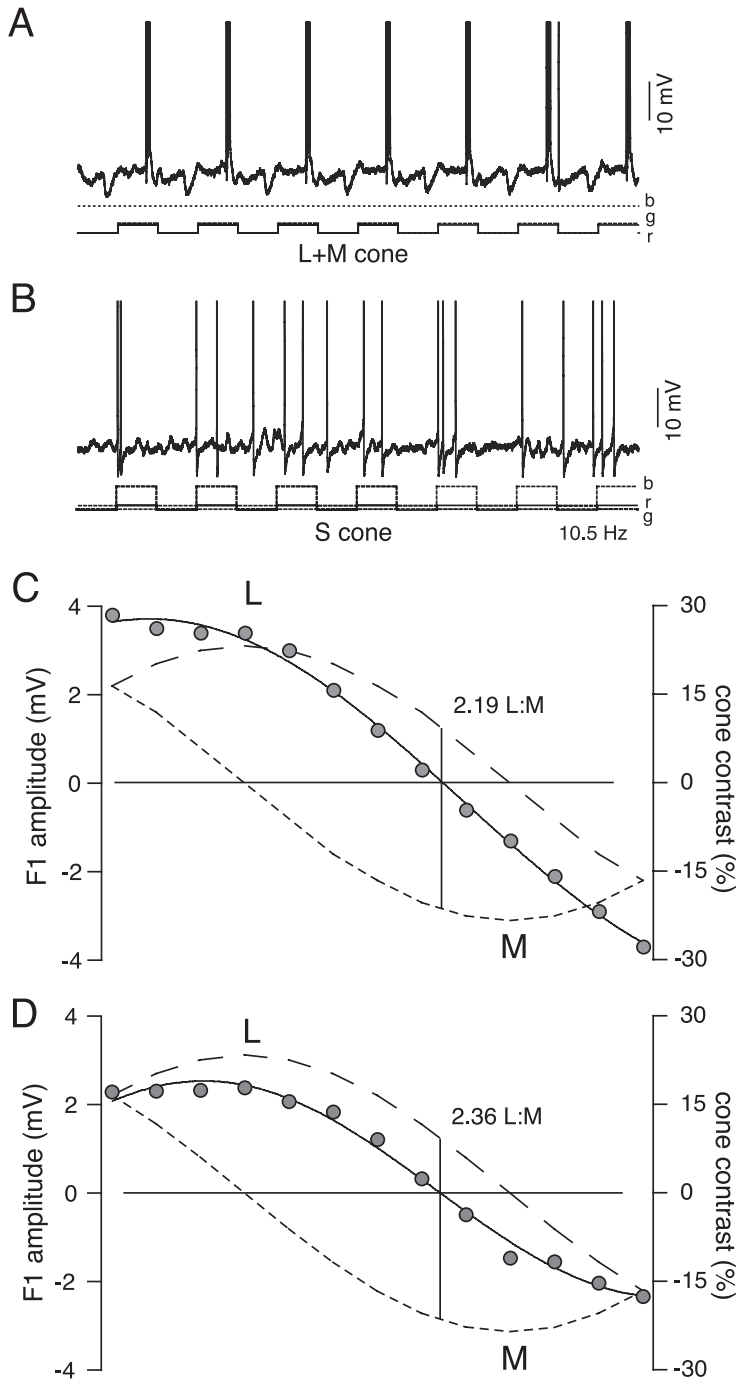

Figure 10. Smooth cells sum L- and M-cone inputs and do not receive any S-cone input. Mean intensities of the red, green, and blue LED's were adjusted to produce equal mean quantal catches in each cone type and amplitudes adjusted to modulate either $\mathrm{L}$ - and $\mathrm{M}$ - or just $\mathrm{S}$-cones. $\boldsymbol{A}$, OFF spiking light responses to $10.5 \mathrm{~Hz}$ square wave $\mathrm{L}+\mathrm{M}$-cone-isolating stimuli of $79 \%$ contrast $(n=3)$. $\boldsymbol{B}$, Spontaneous activity and null response from the same cell as in $\boldsymbol{A}$, to subsequent $10.5 \mathrm{~Hz}$ square wave $\mathrm{S}$-cone-isolating stimuli of $79 \%$ contrast $(n=3)$. C, D, F1 responses (solid circles) from two smooth cells to a stimulus series that systematically varied the percentage and sign of $\mathrm{L}$ - and $\mathrm{M}$-cone contrasts. Negative valued responses represent a 180 degree phase reversal. The data points are enveloped by two broken lines that represent the relative contrast strength of the $\mathrm{L}$ - and $\mathrm{M}$-cone-isolating stimuli that fluctuated between -31 and $31 \%$ contrast. The solid line is a linear fit to the data in which the strength of each of the cone inputs is given by the cone contrast and added by the smooth cell. The ratio of $\mathrm{L}$ - and $\mathrm{M}$-cone contrast gain derived from the point at which the curve fit to the data gives zero amplitude response was 2.19 (L/M) for $\boldsymbol{C}$ and $2.36(\mathrm{~L} / \mathrm{M})$ for $\boldsymbol{D}$.

frequencies possible. For the smooth cells (and for parasol cells recorded similarly) the use of lower quality optics ( $4 \times$ objective) results in significant loss of contrast in the image above $4 \mathrm{cpd}$. Thus it is possible that the spatial resolution of the smooth cell F2 response has been underestimated and might increase with improved optical quality, as we found it to do for parasol cells. It will therefore be important in future work to record from parasol and smooth cells in the same retina and at the same eccentricities using the same stimuli and optical relay to address the question of how the spatial frequency cutoff for the F2 compares between the cell populations.

The smooth cell F2 component shows high contrast sensitivity 
A
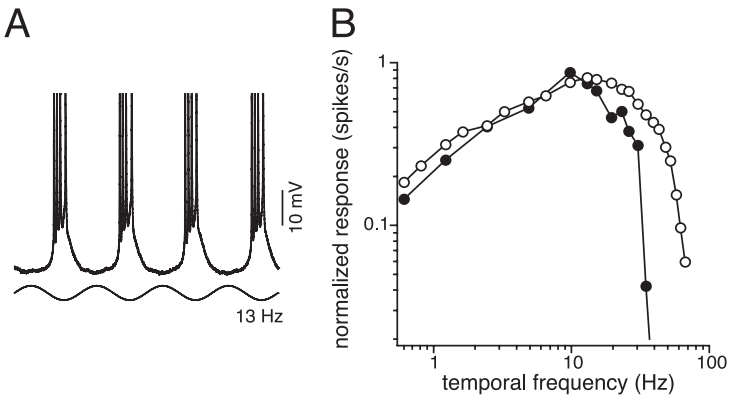

C

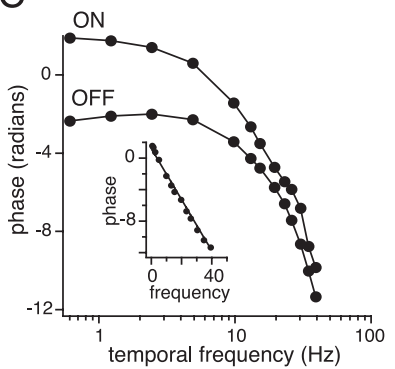

Figure 11. Smooth cells, like parasol cells, have transient responses and encode high temporal frequencies. $\boldsymbol{A}$, Responses to four cycles of a full field $13 \mathrm{~Hz}$ sine wave stimulus of $100 \%$ contrast (stimulus trace below). $\boldsymbol{B}$, Normalized average temporal modulation transfer function for smooth (solid circles, $n=50 \mathrm{~N}$ and $n=20 \mathrm{FF}$ ) and parasol cells (open circles, $n=70 \mathrm{~N}$ and $n=$ $30 \mathrm{FF})$. Stimulus was a $2000 \mu \mathrm{m}$ spot sine wave presented at 50 or $100 \%$ contrast. The SD at $13 \mathrm{~Hz}$, was \pm 0.21 spikes $/ \mathrm{s}$ for smooth cells and \pm 0.36 spikes/s for parasol cells. Peak temporal frequency: smooth cells $13 \pm 5 \mathrm{~Hz}$ (mean $\pm S D ; n=7$ ); and parasol cells $21 \pm 13 \mathrm{~Hz}$ (mean $\pm S D ; n=10$ ). $C$, The corresponding average phase data for the smooth cell temporal modulation transfer function shown in $\boldsymbol{B}$. The latency, determined from the slope (inset) was $52 \pm 3 \mathrm{~ms}$ (mean $\pm S D ; n=5$ ) for $0 \mathrm{~N}$ smooth cells and $38 \pm 0.42 \mathrm{~ms}$ (mean $\pm \mathrm{SD} ; n=2$ ) for OFF smooth cells.
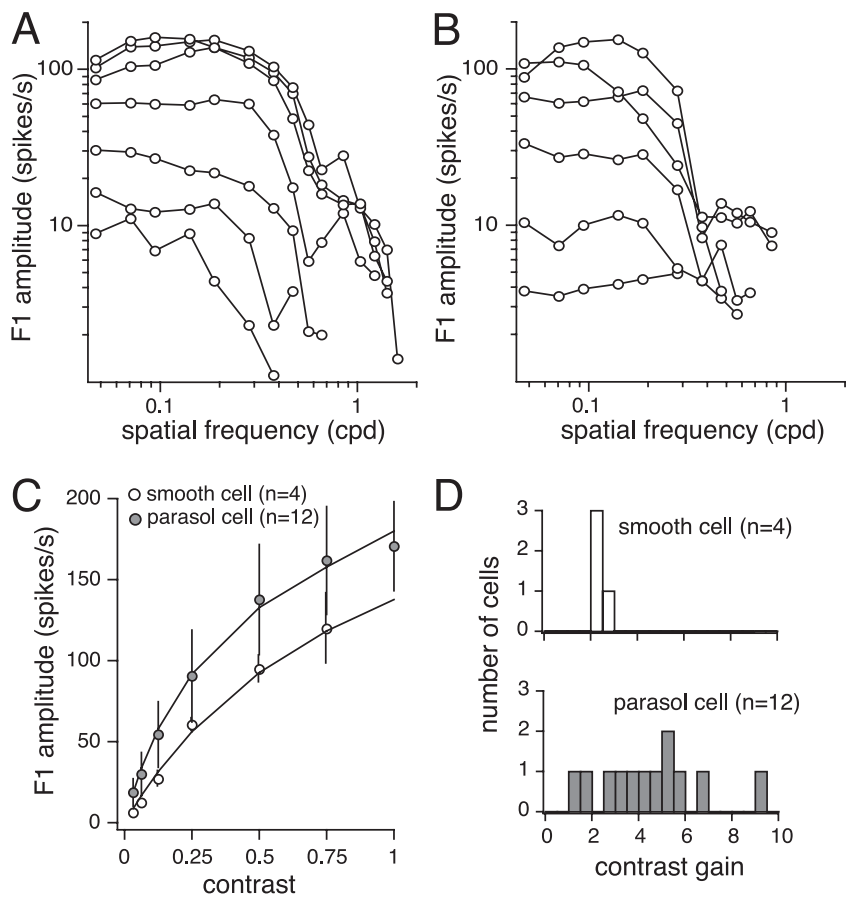

Figure 12. Smooth cells like magnocellular cells have high contrast sensitivity. $A, B, F 1$ responses to drifting gratings at a range of spatial frequencies and contrasts $(3.125 \%, 6.25 \%$, $12.5 \%, 25 \%, 50 \%, 75 \%$, and $100 \%$ ) modulated at $10.5 \mathrm{~Hz}$ for two smooth cells. The response amplitude increases with contrast for both cells. C, Average contrast response functions for smooth cells (open circles, $n=4$ ) and parasol cells (solid circles, $n=12$ ). Stimulus was a sinusoidal grating of near optimal temporal $(10.5 \mathrm{~Hz}$ ) and spatial frequency for each cell (error bars $=1$ SD). The solid lines are average Naka-Rushton fits (see Materials and Methods) that are characterized by their contrast gain defined as the maximal response in impulses per second divided by the semisaturation constant $(a / b)$. $\boldsymbol{D}$, Histogram of individual contrast gain values for smooth cells (above, $n=4$ ) and parasol cells (below, $n=12$ ).

similar to that found for the parasol cell (Fig. 14). We were able to measure the F2 contrast sensitivity in two smooth cells recorded intracellularly and compare these data with comparable parasol data from a larger sample recorded extracellularly (Crook et al., 2008). The F2 response appeared at low contrasts and was evident in the underlying synaptic potential (Fig. $14 A, B$, lower plots) as well as the spike rates (Fig. 14A, B, upper plots). Similar to parasol cells the smooth cells characteristic F2 spatial frequency response and spatial phase independence (Fig. 14D) was also present at

low contrasts suggesting strongly that the F2 component does not arise from a response distortion at high stimulus contrasts. Both of the smooth cells sampled show steep contrast response functions that began to saturate at $50 \%$ contrast; again similar to that found for both the F1 and F2 responses for the larger parasol cell sample. Because of the small sample size we did not attempt to fit the smooth cell F2 contrast response data and determine contrast gain; however, as evident from Figure $14 C$, the initial slopes for the parasol and smooth cell responses are comparable.

In sum, both smooth and parasol cells can be consistently retrogradely labeled from tracer injections made into either the LGN or superior colliculus so a branching projection to both targets is likely (Fig. 15A). Smooth cells have dendritic fields and receptive field center diameters about twice that of parasol cells in mid-peripheral retina. Although anatomically distinct both ganglion cell classes form ON and OFF center subpopulations and show center-surround receptive fields, similar response latencies, high spike discharge rates and high contrast sensitivity, peak temporal responsivity above $10 \mathrm{~Hz}$ and a Y-cell type nonlinear spatial summation. The nonlinear component of the receptive field is present at high spatial frequencies and is spatial phase insensitive (Fig. 15B).

\section{Discussion \\ Previous observations}

Smooth cells were not observed previously when macaque ganglion cells were labeled by tracer injections into LGN, superior colliculus, and pretectum and then targeted for intracellular staining (Rodieck and Watanabe, 1993). In that study a number of novel ganglion cell types were observed but the sample may have been too small to capture the diversity present in the LGN/ collicular projection (Dacey, 2004). Cells that likely correspond to the smooth cells were observed in recent surveys of macaque (Yamada et al., 2005) and human (Peterson and Dacey, 1999) retina that targeted ganglion cells in vitro for intracellular dye injections. It is unlikely however that the smooth cells correspond to the "achromatic garland" cells recently described in macaque foveal retina (Calkins and Sterling, 2007). The garland cells dendritic trees appeared smaller in diameter than that of parasol cells and more broadly stratified within the IPL.

In a recent study using multielectrode array recordings ganglion cells with larger receptive fields than parasol cells were identified (Petrusca et al., 2007). The cells sampled were OFF cells that summed $\mathrm{L}$ and $\mathrm{M}$ input, lacked S-cone input and showed a receptive field diameter that averaged $\sim 3$ times that of the parasol ganglion cells. It is possible that at least some of these cells corresponded to the OFF-center, outer smooth cells, however the peripheral smooth cells characterized here show consistently smaller receptive field diameters $(\sim 2$ times that of parasol cells at comparable eccentricities) and much higher spike discharge rates to drifting gratings even when using much lower contrast stimuli. Also the F2 component measured for the large field cells identified by Petrusca et al., (2007) peaked at lower spatial frequencies $(\sim 1 \mathrm{cpd})$ than that shown here for the smooth cells ( $\sim 2 \mathrm{cpd})$. In this context it is worth noting that, beyond the parasol-Y, midget, and small bistratified blue-ON cells, all other macaque ganglion 
A

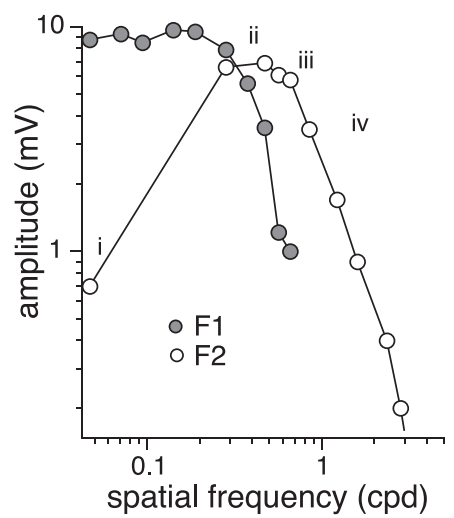

C

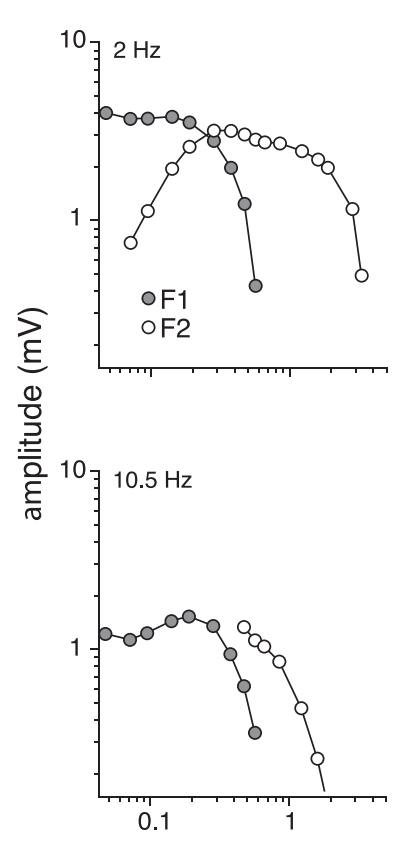

B
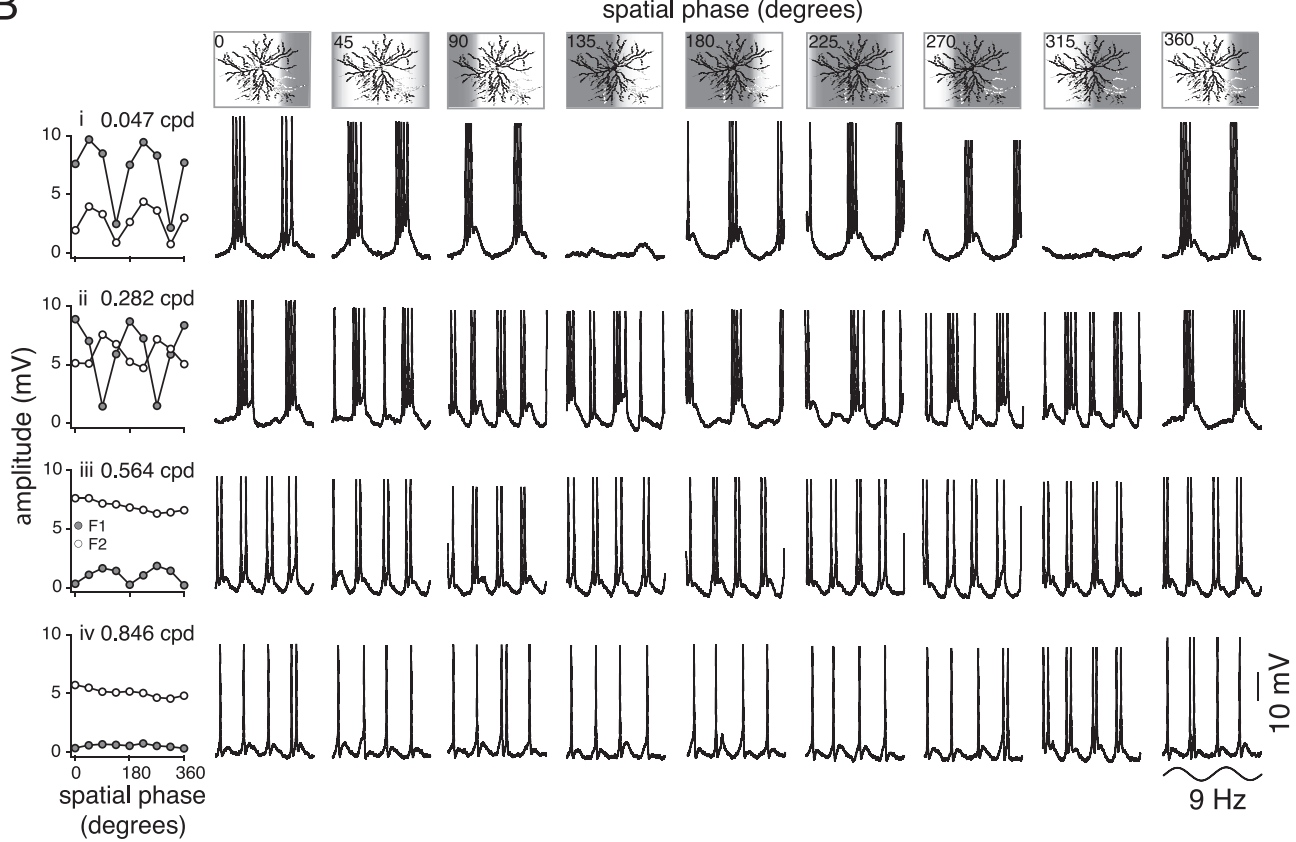
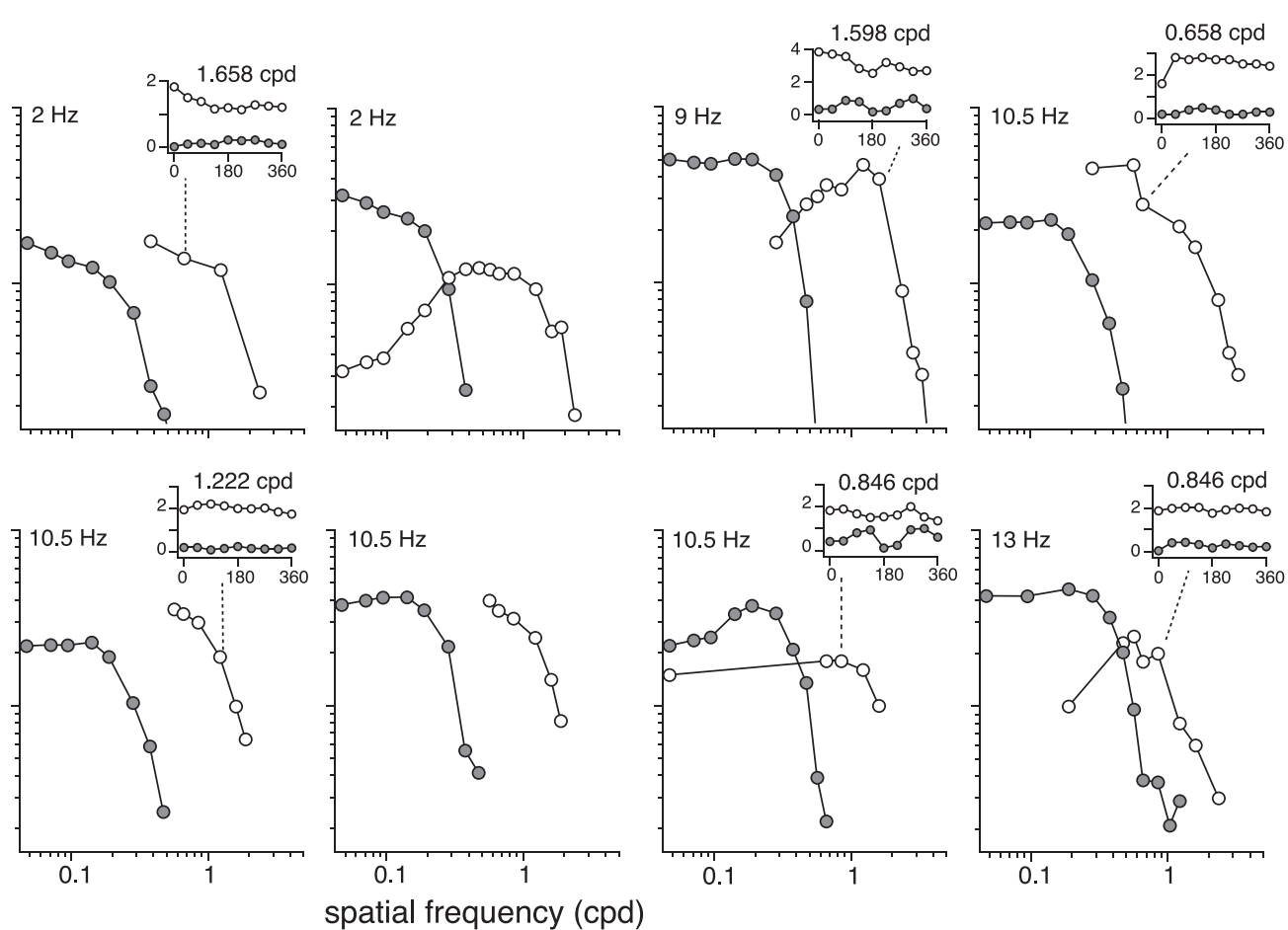

Figure 13. Smooth cells have $\mathrm{Y}$-cell like physiology. $\boldsymbol{A}$, $\mathrm{F} 1$ and second Fourier harmonic ( $\mathrm{F} 2)$ spatial frequency tuning curves. Solid circles are the $\mathrm{F} 1$ responses to drifting sine wave gratings $(2 \mathrm{~Hz}$, $50 \%$ contrast); open circles are the $\mathrm{F} 2$ responses to stationary contrast-reversing grating ( $10.5 \mathrm{~Hz}, 50 \%$ contrast). The $\mathrm{F} 2$ crosses the $\mathrm{F} 1$, a classic $\mathrm{Y}$-cell signature. $\boldsymbol{B}, \mathrm{F} 1$ (solid circles) and $\mathrm{F} 2$ (open circles) responses to contrast reversing gratings as a function of the spatial phase of the stimulus. The spatial frequencies used in plots $\boldsymbol{i}$, ii, iii, and $\boldsymbol{i v}$ are indicated on the $Y$-cell signature in $\boldsymbol{A}$. Responses for each data point are presented to the right with illustrations of the stimulus relative to the cells receptive field above. Data in $\boldsymbol{A}$ and $\boldsymbol{B}$ are from the same cell. At high spatial frequencies (iii and iv) the F2 dominates and is phase insensitive. $C, Y$-cell signatures plotted for 10 other smooth cells. The stimulus is the same as described in $A$, but the temporal frequency of the stimulus varies for each cell as indicated. Five of the $10 \mathrm{Y}$-cell signatures include insets showing that at a spatial frequency greater than the resolution of the F1, F2 responses are phase insensitive.

cell types observed have dendritic fields as large or larger than that of the smooth cells (Dacey et al., 2003; Dacey, 2004); several of these types are achromatic cells that show transient light responses (unpublished observations). Moreover, in the mammalian retina, beyond the alpha-Y cells, a number of other ganglion cell classes with large receptive fields and nonlinear spatial summation have been described (Troy et al., 1989; Rowe and Cox,
1993; Pu et al., 1994; Troy et al., 1995; Demb et al., 1999) and observed at the LGN level (Sur and Sherman, 1982; Spear et al., 1989). In the cat retina the spatially nonlinear, transient W-cell can be distinguished from the alpha-Y cell by a 'sluggish' response characterized by relatively low spike discharge rates (Cleland and Levick, 1974b). Similar low spike rates were observed by Petrusca et al. (2007), for their very large field OFF cells suggesting a pos- 
A
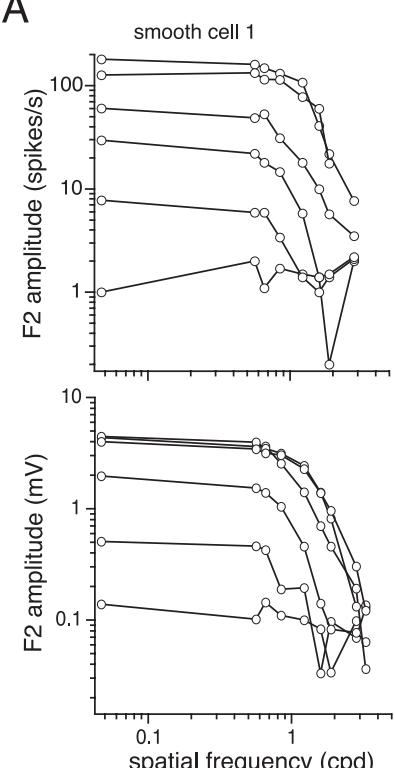

spatial frequency $(\mathrm{cpd})$

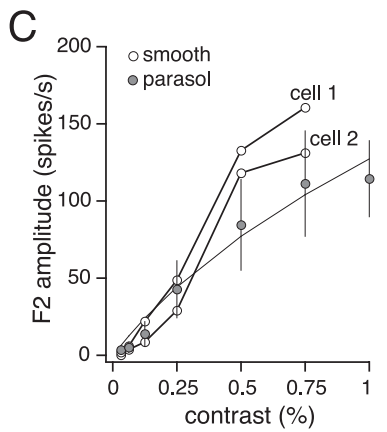

B
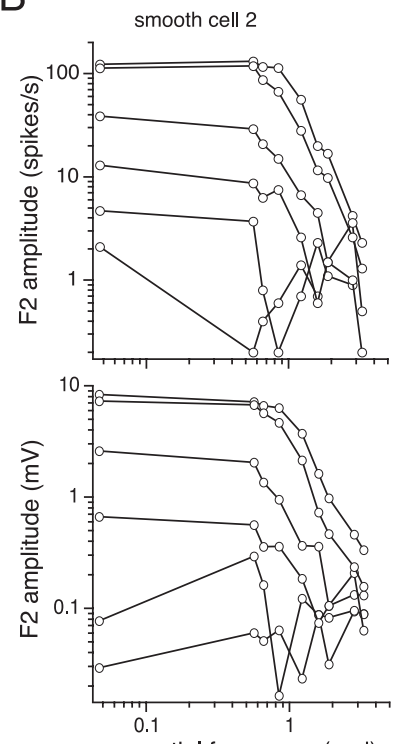

spatial frequency (cpd)

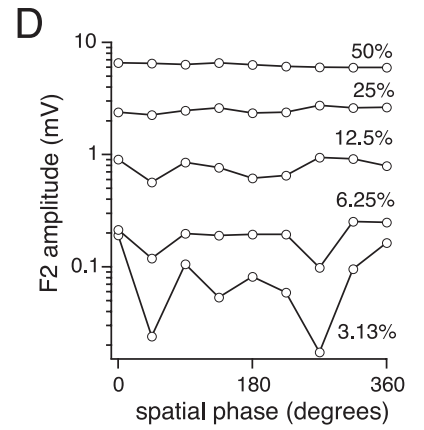

Figure 14. The smooth cells F2 is sensitive to changes in contrast. $\boldsymbol{A}, \boldsymbol{B}, \mathrm{F} 2$ responses, (spikes/s above and $\mathrm{mV}$ below) from two smooth cells to stationary contrast-reversing grating at a range of spatial frequencies and contrasts $(3.125 \%, 6.25 \%, 12.5 \%, 25 \%, 50 \%$, and $75 \%)$ modulated at $10.5 \mathrm{~Hz}$. Response amplitude increases with contrast. $C$, Contrast response functions for two smooth cells (open circles, $n=2$ ) and average contrast response functions for parasol cells (solid circles, $n=12$ ). Stimulus was a contrast-reversing sine wave grating of near optimal temporal $(10.5 \mathrm{~Hz})$ and spatial frequency for each cell. Solid lines join smooth cell data points and average parasol data points are fit with a Naka Rushton saturation function (error bars $=1 S D)$. $\boldsymbol{D}$, Responses to a contrast-reversing grating, of optimal spatial frequency $(0.564$ (pd), as a function of spatial phase. Stimulus was presented at 3.125, 6.25, 12.5, 25, and 50\% contrast and modulated at $10.5 \mathrm{~Hz}$. Response amplitude increases with contrast.

sible link to the cat's sluggish-transient W cells. In the guinea pig retina all ganglion cell types that have been recorded show nonlinear spatial summation (Demb et al., 1999). It is likely therefore that, in addition to the smooth and parasol cells (Crook et al., 2008), multiple pathways derived from low-density ganglion cell populations distinguished by large, achromatic receptive fields, relatively low discharge rates and spatially nonlinear receptive field structure are also present in the primate.

\section{Parasol-alpha-Y versus smooth-Y cells}

Because the morphology, central projections, and physiology of the smooth cells share many features with that of the parasol ganglion cells described in a companion study (Crook et al., 2008) we focused in the Results on a comparison of the smooth cells with their parasol cell counterparts. In Crook et al. (2008) we found that parasol cells show Y-cell receptive field structure and project to the superior colliculus in addition to the well established projection to the magnocellular LGN. These data com-

bined with previously documented anatomical and physiological properties suggest strongly that the parasol cells are the long suspected primate equivalent of the generic mammalian alpha-Y cell (Crook et al., 2008). Thus parasol cells share with other mammalian $\alpha$ cells the largest cell bodies, thickest fast conducting axons, collicular projection, unique neurofibrillar staining and a distinctive tracer-electrical coupling pattern. In contrast the smooth cells can be distinguished from the parasol-alpha cells by a smaller soma and axon diameter and lack of neurofibrillar staining combined with a larger dendritic field size. Whether other anatomical features of the smooth cells, such as tracer coupling, distinguish the smooth cells from the parasol cells remains to be explored.

Beyond the clear anatomical differences the smooth cells share with the parasol cells an $\mathrm{ON}-\mathrm{OFF}$ pathway dichotomy, centersurround receptive field organization, high spike discharge rates and high achromatic contrast gain and temporal sensitivity. Thus the key properties previously attributed to a unitary magnocellular pathway are apparently duplicated in the lower density smooth cell population. The smooth cells therefore appear to provide a second, parallel non-alpha Y-cell projection to the LGN/colliculus in the macaque. Surprisingly, the narrowly monostratified smooth and parasol cell dendrites also precisely costratify in the IPL. Parasol cells receive $80 \%$ or more of their synaptic input from amacrine cells; cone bipolar input derives from identified diffuse cone bipolar types DB2 and DB3 (Jacoby and Marshak, 2000; Jacoby et al., 2000; Marshak et al., 2002; Calkins and Sterling, 2007). Given the summed L- and M-cone input and the IPL costratification it is possible that the basic receptive field properties and cone inputs to the smooth and parasol cells derive from the same or highly overlapping amacrine-bipolar circuitry.

\section{Smooth cells and primate visual pathway diversity}

Where within the LGN do the smooth cells project and what is the functional significance of this pathway? Figure 16 summarizes current knowledge of presumed primate LGN projecting ganglion cell classes that have been both morphologically and physiologically characterized. In addition to the previously recognized midget, parasol-Y, and small bistratified blue-ON cells, the melanopsin-containing giant cells and the smooth-Y cells have been included. Evidence suggests that the small bistratified cells may project to the koniocellular layers (Szmajda et al., 2006) and/or the ventral pair of parvocellular layers (Schiller and Malpeli, 1978) but the precise targets of the smooth and melanopsin cells are not known. We observed that the retrogradely stained smooth cells and parasol cells tended to appear together in the same labeled patches and given their very similar physiology together with the observation that magnocellular Y-cells have high contrast sensitivity a magnocellular projection for the smooth cells is possible. It is also possible that the smooth-Y cells project to the koniocellular layers where, in addition to blue-ON and blue-OFF cells, achromatic receptive fields have been observed in the marmoset (White et al., 1998; Solomon et al., 1999), although cells with the high contrast gain and temporal sensitivity of the smooth cells were not observed and a recent anatomical study of koniocellular projecting ganglion cell types also did not reveal a smooth cell correlate in the marmoset (Szmajda et al., 2008). If the smooth-Y cells did project to the koniocellular layers it is not clear whether this pathway would necessarily relay to primary visual cortex in parallel with the parasol-magnocellular pathway. Some koniocellular LGN relay cells appear to bypass primary visual cortex and project directly to area MT (Sincich et al., 2004), 
A

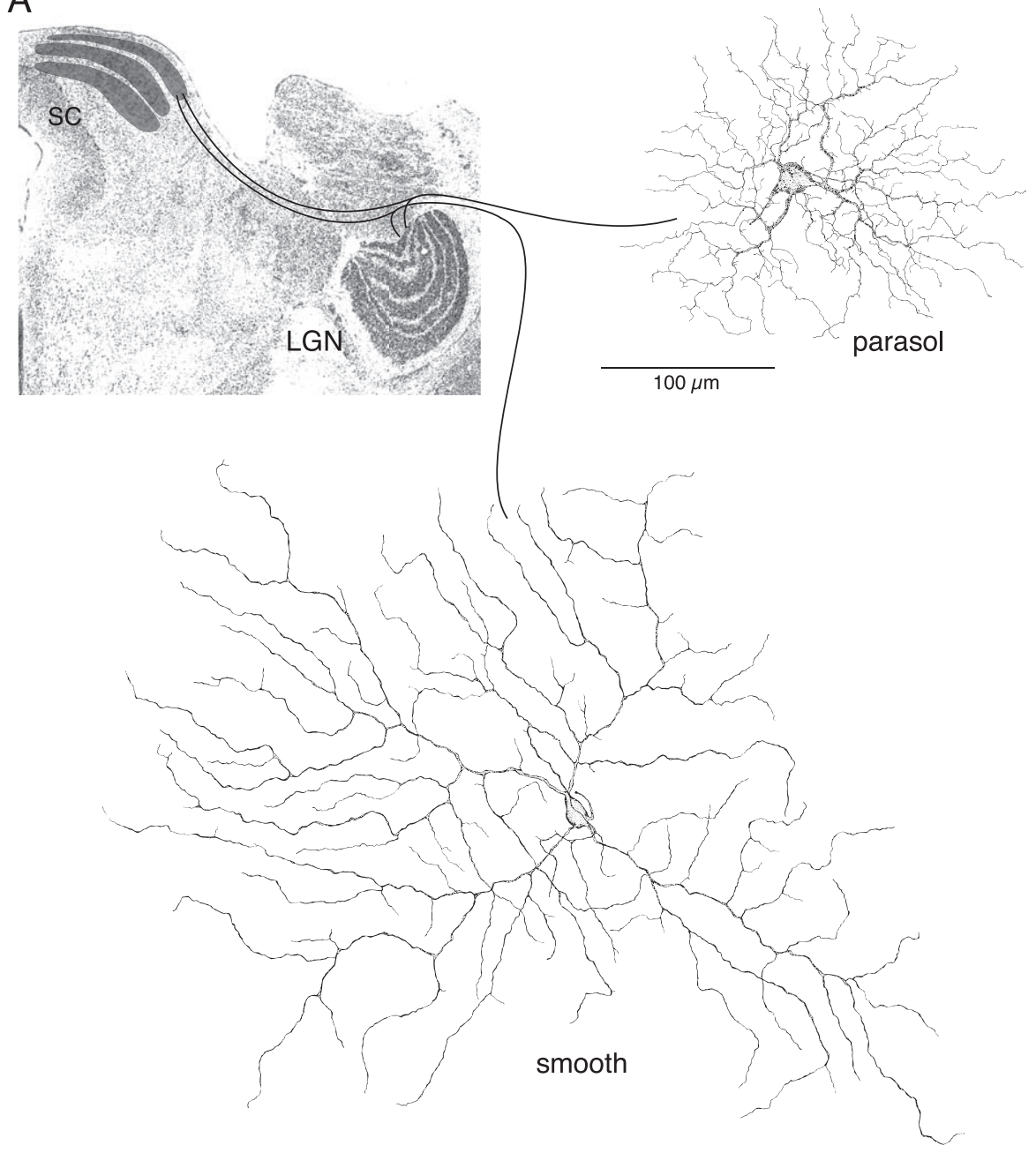

B

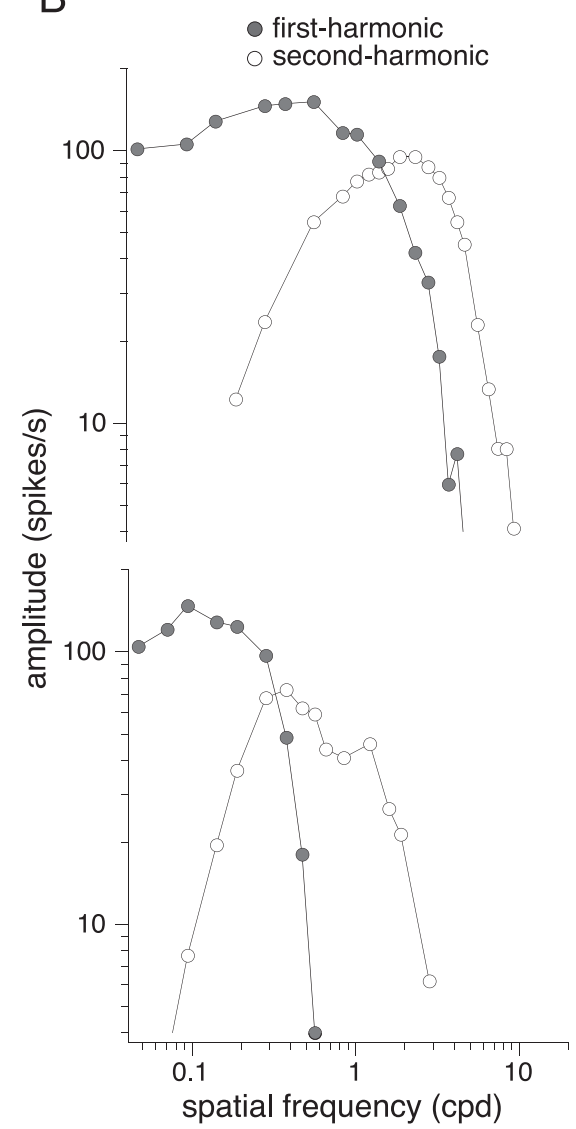

Figure 15. Summary of the central projections, dendritic morphology and receptive field spatial structure for smooth and parasol ganglion cell classes of the macaque retina found in this and a companion study (Crook et al., 2008). A, Smooth cells are about twice the dendritic field diameter of parasol cells at a given retinal eccentricity; both cell types can be retrogradely labeled from tracer injections into either the LGN or the superior colliculus and may therefore project to both structures via branching axons. B, Smooth (bottom plot) and parasol cells (top plot) show center surround receptive field structure ( $\mathrm{F} 1$ component, filled circles) but smooth cells have larger receptive field center diameters. Both cell groups show a strong Y-cell signature, a second harmonic response ( $\mathrm{F} 2$ component, open circles) that extends to high spatial frequencies.

an extrastriate cortical area associated with the processing of object motion. A direct input to MT from the ganglion cells with the large achromatic receptive fields and the Y-cell properties of the smooth cell might not be surprising.

Why multiple Y-cell pathways, with shared central targets, similar key physiological properties, and overlapping or possibly identical presynaptic retinal microcircuits-differing primarily in spatial scale? We speculate that this pattern may to some extent be analogous to that for the rabbit direction selective (DS) ganglion cells (Vaney et al., 2001). DS cells can be divided into multiple populations that tile the retina independently but costratify in the IPL, share presynaptic circuitry, central targets and the same basic directionally selective light response. However each rabbit DS population varies in directional tuning and in this way multiple anatomically distinct pathways with subtle physiological distinctions arise from a single retinal microcircuit. Similarly the smooth and parasol cells may be components of a single microcircuit that gives rise to multiple, parallel achromatic pathways that vary primarily in spatial scale. Thus one rationale for extreme visual pathway diversity may be to create multiple channels that vary in tuning along a single dimension. For the direction selective cells the variable is axis of preferred motion direction and for the achromatic channel subserving pattern vision the key variable is spatial tuning. In this regard human spatial vision has been modeled as an array of multiple achromatic channels that at an early processing stage appear as some number of independent filters each responsive to a narrow range of spatial frequencies, with each channel capable of spatial frequency selective contrast adaptation (for review, see Wilson and Wilkinson, 2002). There is much evidence, spanning 30 years of research, that selectively adaptable bandpass spatial channels originate at the level of primary visual cortex [e.g., Movshon and Lennie (1979) and Duong and Freeman (2007)]. However given the recent evidence for significant contrast adaptation at the level of the primate LGN and retina (Chander and Chichilnisky, 2001; Solomon et al., 2004) together with as yet unexplored pathway diversity in the retinogeniculate projection, it is possible that the earliest stages in the elaboration of multiple achromatic spatial channels begins within the retina.

\section{References}

Baylor DA, Nunn BJ, Schnapf JL (1987) Spectral sensitivity of cones of the monkey Macaca fascicularis. J Physiol 390:145-160.

Benardete EA, Kaplan E (1999) The dynamics of primate M retinal ganglion cells. Vis Neurosci 16:355-368. 


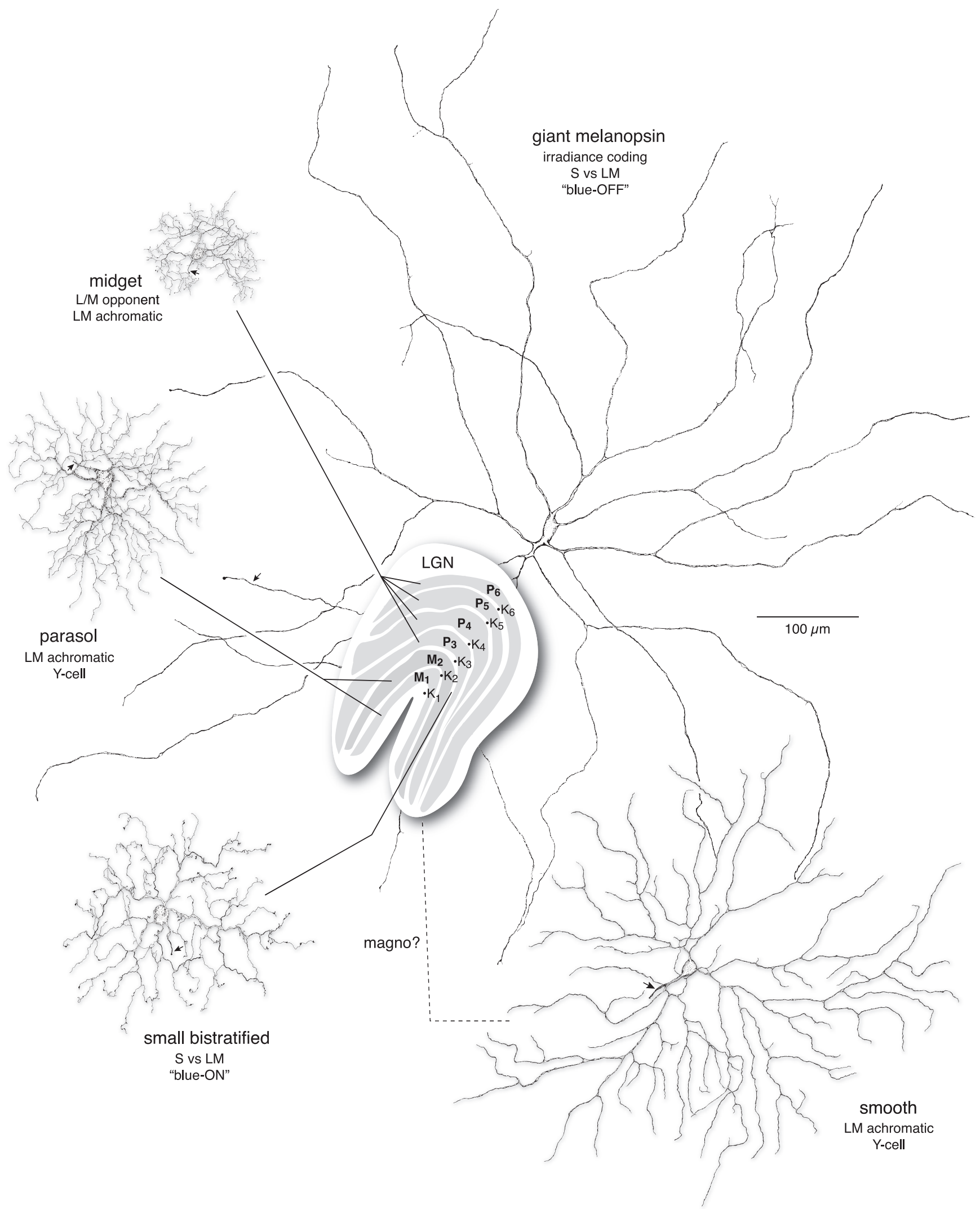

Figure 16. Physiologically and morphologically characterized ganglion cell types that project to the macaque LGN. Color opponent and nonopponent midget cells project to the parvocellular layers. Parasol-Y cells project to the magnocellular layers. Small bistratified blue-ON cells may project to the koniocellular layers. The target of the smooth-Y cell is unknown but high achromatic contrast and temporal sensitivity and Y-cell signature suggest a termination in the magnocellular or possibly koniocellular layers. The target of the melanopsin-containing luminance cells is also unknown but S-cone input to these cells suggests a projection to the koniocellular layers. 
Berson DM, Pu M, Famiglietti EV (1998) The zeta cell: a new ganglion cell type in cat retina. J Comp Neurol 399:269-288.

Burkhardt DA, Fahey PK, Sikora MA (2007) Retinal bipolar cells: temporal filtering of signals from cone photoreceptors. Vis Neurosci 24:765-774.

Calkins DJ, Sterling P (2007) Microcircuitry for two types of achromatic ganglion cell in primate fovea. J Neurosci 27:2646-2653.

Callaway EM (2005) Structure and function of parallel pathways in the primate early visual system. J Physiol 566:13-19.

Chander D, Chichilnisky EJ (2001) Adaptation to temporal contrast in primate and salamander retina. J Neurosci 21:9904-9916.

Chichilnisky EJ, Kalmar RS (2002) Functional asymmetries in ON and OFF ganglion cells of primate retina. J Neurosci 22:2737-2747.

Cleland BG, Levick WR (1974a) Properties of rarely encountered types of ganglion cells in the cat's retina and an overall classification. J Physiol 240:457-492.

Cleland BG, Levick WR (1974b) Brisk and sluggish concentrically organized ganglion cells in the cat's retina. J Physiol 240:421-456.

Cleland BG, Dubin MW, Levick WR (1971) Sustained and transient neurons in the cat's retina and lateral geniculate nucleus. J Physiol 217:473-496

Crook JD, Peterson BB, Packer OS, Robinson FR, Troy JB, Dacey DM (2008) $\mathrm{Y}$-cell receptive field and collicular projection of parasol ganglion cells in macaque monkey retina. J Neurosci 28:11277-11291.

Dacey DM (1989) Monoamine-accumulating ganglion cell type of the cat's retina. J Comp Neurol 288:59-80.

Dacey DM (1993a) The mosaic of midget ganglion cells in the human retina. J Neurosci 13:5334-5355.

Dacey DM (1993b) Morphology of a small-field bistratified ganglion cell type in the macaque and human retina. Vis Neurosci 10:1081-1098.

Dacey DM (2004) Origins of perception: retinal ganglion cell diversity and the creation of parallel visual pathways. In: The cognitive neurosciences, Ed 3 (Gazzaniga MS, ed), pp 281-301. Cambridge, MA: MIT.

Dacey DM, Brace S (1992) A coupled network for parasol but not midget ganglion cells in the primate retina. Vis Neurosci 9:279-290.

Dacey DM, Lee BB (1994) The blue-ON opponent pathway in primate retina originates from a distinct bistratified ganglion cell type. Nature 367:731-735.

Dacey DM, Lee BB, Stafford DK, Pokorny J, Smith VC (1996) Horizontal cells of the primate retina: cone specificity without spectral opponency. Science 271:656-659.

Dacey DM, Diller LC, Verweij J, Williams DR (2000) Physiology of L- and $\mathrm{M}$-cone inputs to $\mathrm{H} 1$ horizontal cells in the primate retina. J Opt Soc Am A Opt Image Sci Vis 17:589-596.

Dacey DM, Peterson BB, Robinson FR, Gamlin PD (2003) Fireworks in the primate retina: in vitro photodynamics reveals diverse LGN-projecting ganglion cell types. Neuron 37:15-27.

Dacey DM, Liao H-W, Peterson BB, Robinson FR, Smith VC, Pokorny J, Yau K-W, Gamlin PD (2005) Melanopsin-expressing ganglion cells in primate retina signal colour and irradiance and project to the LGN. Nature 433:749-754.

Demb JB, Haarsma L, Freed MA, Sterling P (1999) Functional circuitry of the retinal ganglion cell's nonlinear receptive field. J Neurosci 19:9756-9767.

Diller L, Packer OS, Verweij J, McMahon MJ, Williams DR, Dacey DM (2004) L and M cone contributions to the midget and parasol ganglion cell receptive fields of macaque monkey retina. J Neurosci 24:1079-1088.

Duong T, Freeman RD (2007) Spatial frequency specific contrast adaptation originates in the primary visual cortex. J Neurophysiol 98:187-195.

Enroth-Cugell C, Robson JG, Schweitzer-Tong DE, Watson AB (1983) Spatio-temporal interactions in cat retinal ganglion cells showing linear spatial summation. J Physiol 341:279-307.

Estévez O, Spekreijse H (1982) The "silent substitution" method in visual research. Vision Res 22:681-691.

Field GD, Chichilnisky EJ (2007) Information processing in the primate retina: circuitry and coding. Annu Rev Neurosci 30:1-30.

Frishman LJ, Freeman AW, Troy JB, Schweitzer-Tong DE, Enroth-Cugell C (1987) Spatiotemporal frequency responses of cat retinal ganglion cells. J Gen Physiol 89:599-628.

Holdefer RN, Norton TT (1995) Laminar Organization of receptive field properties in the dorsal lateral geniculate nucleus of the tree shrew ( $T u$ paiaglis belangeri). J Comp Neurol 358:401-413.

Irvin GE, Casagrande VA, Norton TT (1993) Center/surround relation- ships of magnocellular, parvocellular, and koniocellular relay cells in primate lateral geniculate nucleus. Vis Neurosci 10:363-373.

Isayama T, Berson DM, Pu M (2000) Theta ganglion cell type of cat retina. J Comp Neurol 417:32-48.

Jacoby RA, Marshak DW (2000) Synaptic connections of DB3 diffuse bipolar cell axons in macaque retina. J Comp Neurol 416:19-29.

Jacoby RA, Wiechmann AF, Amara SG, Leighton BH, Marshak DW (2000) Diffuse bipolar cells provide input to OFF parasol ganglion cells in the macaque retina. J Comp Neurol 416:6-18.

Kaplan E, Lee BB, Shapley RM (1990) New views of primate retinal function. Prog Retin Eye Res 9:273-336.

Lee BB (1999) Receptor inputs to primate ganglion cells. In: Color vision: from genes to perception (Gegenfurtner KR, Sharpe LT, eds), pp 203-218. New York: Cambridge UP.

Lee BB, Martin PR, Valberg A (1988) The physiological basis of heterochromatic flicker photometry demonstrated in the ganglion cells of the macaque retina. J Physiol 404:323-347.

Lee BB, Pokorny J, Smith VC, Kremers J (1994) Responses to pulses and sinusoids in macaque ganglion cells. Vision Res 34:3081-3096.

Lennie P, Movshon JA (2005) Coding of color and form in the geniculostriate visual pathway (invited review). J Opt Soc Am A Opt Image Sci Vis 22:2013-2033.

Marshak DW, Yamada ES, Bordt AS, Perryman WC (2002) Synaptic input to an ON parasol ganglion cell in the macaque retina: a serial section analysis. Vis Neurosci 19:299-305.

Martin PR, White AJR, Goodchild AK, Wilder HD, Sefton AE (1997) Evidence that blue-on cells are part of the third geniculocortical pathway in primates. Eur J Neurosci 9:1536-1541.

Masland RH, Raviola E (2000) Confronting complexity: strategies for understanding the microcircuitry of the retina. Annu Rev Neurosci 23:249-284.

Masland RH, Martin PR (2007) The unsolved mystery of vision. Curr Biol 17:577-582.

Meister M, Berry MJ 2nd (1999) The neural code of the retina. Neuron 22:435-450.

Movshon JA, Lennie P (1979) Pattern-selective adaptation in visual cortical neurones. Nature 278:850-852.

Packer O, Diller LC, Verweij J, Lee BB, Pokorny J, Williams DR, Dacey DM, Brainard DH (2001) Characterization and use of a digital light projector for vision research. Vis Res 41:427-439.

Peichl L, Wässle H (1979) Size, scatter and coverage of ganglion cell receptive field centres in the cat retina. J Physiol 291:117-141.

Peichl L, Wässle H (1983) The structural correlate of the receptive field centre of X ganglion cells in the cat retina. J Physiol 341:309-324.

Peterson BB, Dacey DM (1999) Morphology of wide-field, monostratified ganglion cells of the human retina. Vis Neurosci 16:107-120.

Petrusca D, Grivich MI, Sher A, Field GD, Gauthier JL, Greschner M, Shlens J, Chichilnisky EJ, Litke AM (2007) Identification and characterization of a Y-like primate retinal ganglion cell type. J Neurosci 27:11019-11027.

$\mathrm{Pu}$ M, Berson DM, Pan T (1994) Structure and function of retinal ganglion cells innervating the cat's geniculate wing: an in vitro study. J Neurosci 14:4338-4358.

Rockhill RL, Euler T, Masland RH (2000) Spatial order within but not between types of retinal neurons. Proc Natl Acad Sci U S A 97:2303-2307.

Rockhill RL, Daly FJ, MacNeil MA, Brown SP, Masland RH (2002) The diversity of ganglion cells in a mammalian retina. J Neurosci 22:3831-3843.

Rodieck RW, Watanabe M (1993) Survey of the morphology of macaque retinal ganglion cells that project to the pretectum, superior colliculus, and parvicellular laminae of the lateral geniculate nucleus. J Comp Neurol 338:289-303.

Roska B, Werblin F (2001) Vertical interactions across ten parallel, stacked representations in the mammalian retina. Nature 410:583-587.

Rowe MH, Cox JF (1993) Spatial receptive-field structure of cat retinal W cells. Vis Neurosci 10:765-779.

Schiller PH, Malpeli JG (1978) Functional specificity of lateral geniculate nucleus laminae of the rhesus monkey. J Neurophysiol 41:788-797.

Silveira LCL, Perry VH (1991) The topography of magnocellular projecting ganglion cells (M-ganglion cells) in the primate retina. Neuroscience 40:217-237.

Sincich LC, Park KF, Wohlgemuth MJ, Horton JC (2004) Bypassing V1: a direct geniculate input to area MT. Nat Neurosci 7:1123-1128. 
So YT, Shapley R (1979) Spatial properties of X and Y cells in the lateral geniculate nucleus of the cat conduction and velocities of their inputs. Exp Brain Res 36:533-550.

Solomon SG, Lennie P (2007) The machinery of colour vision. Nat Rev Neurosci 8:276-286.

Solomon SG, White AJR, Martin PR (1999) Temporal contrast sensitivity in the lateral geniculate nucleus of a New World monkey, the marmoset Callithrix jacchus. J Physiol 517:907-917.

Solomon SG, Peirce JW, Dhruv NT, Lennie P (2004) Profound contrast adaptation early in the visual pathway. Neuron 42:155-162.

Spear PD, McCall MA, Tumosa N (1989) W- and Y-cells in the C layers of the cat's lateral geniculate nucleus: normal properties and effects of monocular deprivation. J Neurophysiol 61:58-73.

Spitzer H, Hochstein S (1985) Simple- and complex-cell response dependences on stimulation parameters. J Neurophysiol 53:1244-1265.

Stein JJ, Berson DM (1995) On the distribution of gamma cells in the cat retina. Vis Neurosci 12:687-700.

Stein JJ, Johnson SA, Berson DM (1996) Distribution and coverage of beta cells in the cat retina. J Comp Neurol 372:597-617.

Stone J (1983) Parallel processing in the visual system: the classification of retinal ganglion cells and its impact on the neurobiology of vision. New York: Plenum.

Sur M, Sherman SM (1982) Linear and non-linear W-cells in the C-laminae of the cat's lateral geniculate nucleus. J Neurophysiol 47:869-884.

Szmajda BA, Buzás P, Fitzgibbon T, Martin PR (2006) Geniculocortical relay of blue-off signals in the primate visual system. Proc Natl Acad Sci U S A 103:19512-19517.

Szmajda BA, Grünert U, Martin PR (2008) Retinal ganglion cell inputs to the koniocellular pathway. J Comp Neurol 510:251-268.

Tailby C, Solomon SG, Dhruv NT, Majaj NJ, Sokol SH, Lennie P (2007) A new code for contrast in the primate visual pathway. J Neurosci 27:3904-3909.

Troy JB, Einstein G, Schuurmans RP, Robson JG, Enrothe-Cugell C (1989)
Responses to sinusoidal gratings of two types of very nonlinear retinal ganglion cells of cat. Vis Neurosci 3:213-223.

Troy JB, Schweitzer-Tong DE, Enroth-Cugell C (1995) Receptive-field properties of Q retinal ganglion cells of the cat. Vis Neurosci 12:285-300.

Vaney D, He S, Taylor W, Levick W (2001) Direction-selective ganglion cells in the retina. In: Motion vision: computational, neural and ecological constraints (Zanker J, Zeil J, eds), pp 13-56. Berlin: Springer.

Vaney DI (1994) Territorial organization of direction-selective ganglion cells in rabbit retina. J Neurosci 14:6301-6316.

Vaney DI, Peichl L, Wässle H, Illing RB (1981) Almost all ganglion cells in the rabbit retina project to the superior colliculus. Brain Res 212:447-453.

Wässle H, Riemann HJ (1978) The mosaic of nerve cells in the mammalian retina. Proc R Soc Lond B Biol Sci 200:441-461.

Wässle H, Peichl L, Boycott BB (1981) Dendritic territories of cat retinal ganglion cells. Nature 292:344-345.

Wässle H, Grünert U, Röhrenbeck J, Boycott BB (1989) Cortical magnification factor and the ganglion cell density of the primate retina. Nature 341:643-646.

Watanabe M, Rodieck RW (1989) Parasol and midget ganglion cells of the primate retina. J Comp Neurol 289:434-454.

White AJ, Solomon SG, Martin PR (2001) Spatial properties of koniocellular cells in the lateral geniculate nucleus of the marmoset Callithrix jacchus. J Physiol 533:519-535.

White AJR, Wilder HD, Goodchild AK, Sefton AJ, Martin PR (1998) Segregation of receptive field properties in the lateral geniculate nucleus of a new-world monkey, the marmoset Callithrix jacchus. J Neurophysiol 80:2063-2076.

Wilson HR, Wilkinson F (2002) Spatial channels in vision and spatial pooling. In: The visual neurosciences (Chalupa LM, Werner JS, eds), pp 1060 1068. Cambridge, MA: MIT.

Yamada ES, Bordt AS, Marshak DW (2005) Wide-field ganglion cells in macaque retinas. Vis Neurosci 22:383-393. 